COUNCIL ELECTROMAGNETIC AND MAGNETIC AIRBORNE GEOPHYSICAL SURVEY DATA COMPILATION

Burns, L.E., Barefoot, J.D., and Stevens Exploration Management Corp.

Geophysical Report 2019-6

2019

STATE OF ALASKA

DEPARTMENT OF NATURAL RESOURCES

DIVISION OF GEOLOGICAL \& GEOPHYSICAL SURVEYS
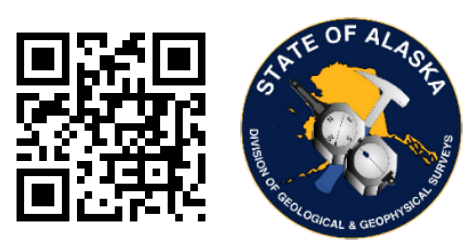
STATE OF ALASKA

Michael J. Dunleavy, Governor

DEPARTMENT OF NATURAL RESOURCES

Corri A. Feige, Commissioner

DIVISION OF GEOLOGICAL \& GEOPHYSICAL SURVEYS

Steve Masterman, State Geologist \& Director

Publications produced by the Division of Geological \& Geophysical Surveys are available to download from the DGGS website (dggs.alaska.gov). Publications on

hard-copy or digital media can be examined or purchased in the Fairbanks office:

Alaska Division of Geological \& Geophysical Surveys (DGGS)

3354 College Road | Fairbanks, Alaska 99709-3707

Phone: 907.451 .5010 | Fax 907.451.5050

dggspubs@alaska.gov $\mid$ dggs.alaska.gov

DGGS publications are also available at:

Alaska State Library, Historical

Collections \& Talking Book Center

395 Whittier Street

Juneau, Alaska 99801

Alaska Resource Library and

Information Services (ARLIS)

3150 C Street, Suite 100

Anchorage, Alaska 99503

\section{Suggested citation:}

Burns, L.E., Barefoot, J.D., and Stevens Exploration Management Corp., 2019, Council electromagnetic and magnetic airborne geophysical survey data compilation: Alaska Division of Geological \& Geophysical Surveys Geophysical Report 2019-6.

http://doi.org/10.14509/30172
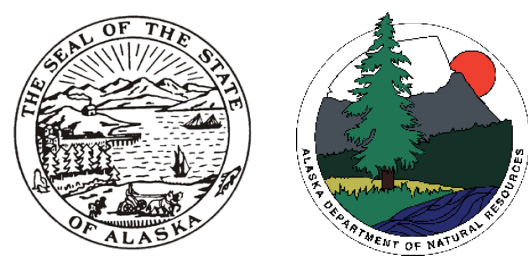


\title{
COUNCIL ELECTROMAGNETIC AND MAGNETIC AIRBORNE GEOPHYSICAL SURVEY DATA COMPILATION
}

Burns, L.E., ${ }^{1}$ Barefoot, J.D. ${ }^{1}$, and Stevens Exploration Management Corp.

\begin{abstract}
This geophysical survey is located in western Alaska on the Seward Peninsula in the Council and Nome mining districts, about 750 kilometers west of Fairbanks, Alaska and about 50 kilometers east of Nome, Alaska. Frequency domain electromagnetic and magnetic data were collected with the DIGHEMV system in August 2002. A total of 4558.9 line kilometers were collected covering 1649.1 square kilometers. Line spacing was 400 meters (m). Data were collected $30 \mathrm{~m}$ above the ground surface from a helicopter towed sensor platform ("bird") on a $30 \mathrm{~m}$ long line.

\section{PURPOSE}

This airborne geophysical survey is part of a program to acquire data on Alaska's most promising mineral belts and districts. The information acquired is aimed at catalyzing new private sector exploration, discovery, and ultimate development and production. The purpose of the survey was to map the magnetic and conductive properties of the survey area. The area has produced more than 1 million ounces of placer gold; recently active lode gold prospects include Bluff, Albion, and Big Hurrah. Other gold and base-metal anomalies, altered zones, favorable lithologies, and structural zones are known to exist throughout the survey area.
\end{abstract}

\section{SURVEY OVERVIEW DESCRIPTION}

This document provides an overview of the survey and includes text and figures of select primary and derivative products of this survey. A table of digital data packages available for download is provided to assist users in data selection. For reference, a catalog of the available maps is presented in reduced resolution. Please consult the metadata, project report, and digital data packages for more information and data.

\section{ACKNOWLEDGMENTS}

Funding was provided by the Alaska State Legislature as part of the DGGS Airborne Geophysical/Geological Mineral Inventory (AGGMI) program.

\footnotetext{
${ }^{1}$ Alaska Division of Geological \& Geophysical Surveys, 3354 College Road, Fairbanks, Alaska 99709-3707
} 


\begin{tabular}{|c|c|c|}
\hline Data Type & Provider & Description \\
\hline ascii_data & contractor & ASCll format line data, other ASCII data \\
\hline databases_geosoft & contractor & $\begin{array}{l}\text { Geosoft format database of final line data, other } \\
\text { Geosoft format databases }\end{array}$ \\
\hline documents & contractor and DGGS & $\begin{array}{l}\text { Project and field reports, survey background } \\
\text { information, gridded data explanations, other } \\
\text { documentation }\end{array}$ \\
\hline grids_ermapper & contractor and DGGS & $\begin{array}{l}\text { Geographically registered gridded data, ER Mapper } \\
\text { ERS format }\end{array}$ \\
\hline grids_geosoft & contractor and DGGS & $\begin{array}{l}\text { Geosoft-format binary grids, these grids can be } \\
\text { viewed in ESRI ArcMap using a free plugin from } \\
\text { Geosoft, or the free viewer available from Geosoft }\end{array}$ \\
\hline images_registered & DGGS & GeoTiff format images of all gridded data \\
\hline $\mathrm{kmz}$ & contractor & $\begin{array}{l}\text { keyhole markup language }(\mathrm{kml}) \mathrm{kmz} \text { archive files of } \\
\text { project data. Viewable in Google Earth and other } \\
\text { compatible programs }\end{array}$ \\
\hline maps_pdf_format & contractor & Printable maps in pdf format \\
\hline maps_prn_format & contractor & $\begin{array}{l}\text { Printable maps in HPGL/G printer file format with } \\
\text { extension .prn }\end{array}$ \\
\hline profiles_stacked & contractor & $\begin{array}{l}\text { Distance-based profiles of the digitally recorded } \\
\text { geophysical data are generated and plotted at an } \\
\text { appropriate scale. The profiles display } \\
\text { electromagnetic anomalies with their respective } \\
\text { interpretive symbols. Printable in pdf format. }\end{array}$ \\
\hline vector_data & contractor and DGGS & $\begin{array}{l}\text { Line path, data contours, and survey boundary in } \\
\text { ESRI shape file (SHP) format, ESRI Geodatabase } \\
\text { format, and/or AutoCAD dxf format. }\end{array}$ \\
\hline video_flightpath & contractor & Survey flight path downward facing video \\
\hline
\end{tabular}




\section{REFERENCES}

Akima, H., 1970, A new method of interpolation and smooth curve fitting based on local procedures: Journal of the Association of Computing Machinery, v. 17, n. 4, p. 589-602.

Burns, L.E., Fugro Airborne Surveys, and Stevens Exploration Management Corp., 2003, Plot files of the airborne geophysical survey data of the Council area, Seward Peninsula, Alaska: Alaska Division of Geological \& Geophysical Surveys Geophysical Report 2003-1, 1 DVD. http://doi.org/10.14509/2884

Burns, L.E., and Clautice, K.H., 2003, Portfolio of aeromagnetic and resistivity maps of the Council area, Seward Peninsula, Alaska: Alaska Division of Geological \& Geophysical Surveys Geophysical Report 2003-4, 16 p. http://doi.org/10.14509/2903

Burns, L.E., and Fugro Airborne Surveys, 2003, Line, gridded, and vector data of the airborne geophysical survey data for the Council area, Seward Peninsula, Alaska: Alaska Division of Geological \& Geophysical Surveys Geophysical Report 2003-2, 1 DVD. http://doi.org/10.14509/2902

Pritchard, R.A., and Fugro Airborne Surveys, 2003, Project report of the airborne geophysical survey of the Council area, Seward Peninsula, Alaska: Alaska Division of Geological \& Geophysical Surveys Geophysical Report 2003-3, 239 p., 2 sheets, scale 1:63,360. http://doi.org/10.14509/3247 


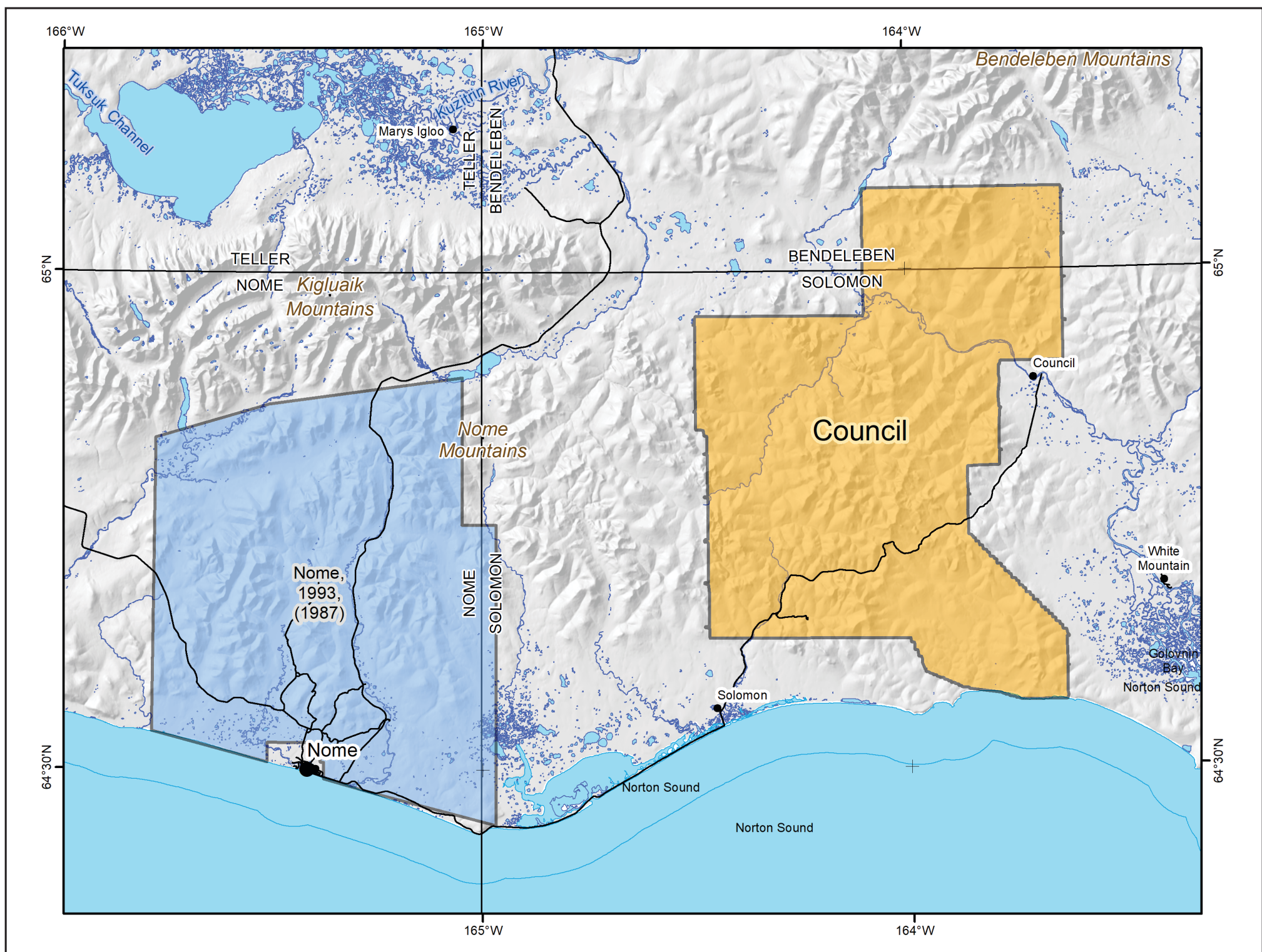

Figure 1. Council electromagnetic and magnetic airborne geophysical survey location shown on Seward Peninsula, western Alaska (inset). Circle survey area shown with adjacent DGGS geophysical surveys, landmarks, relevant 1:250,000-scale quadrangle boundaries, mountain ranges, rivers, glaciers, and elevation hillshade.

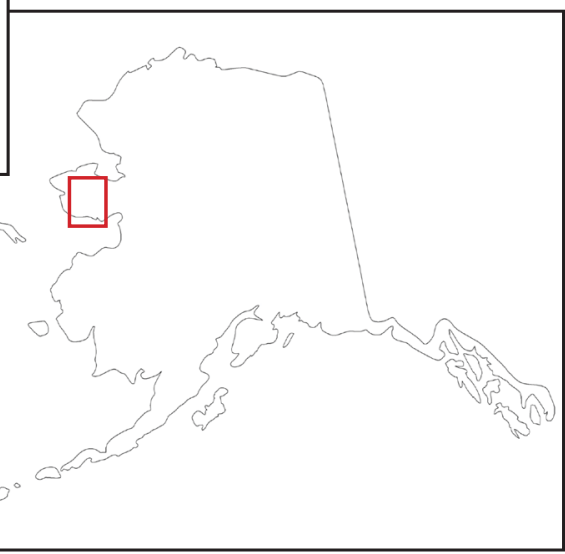




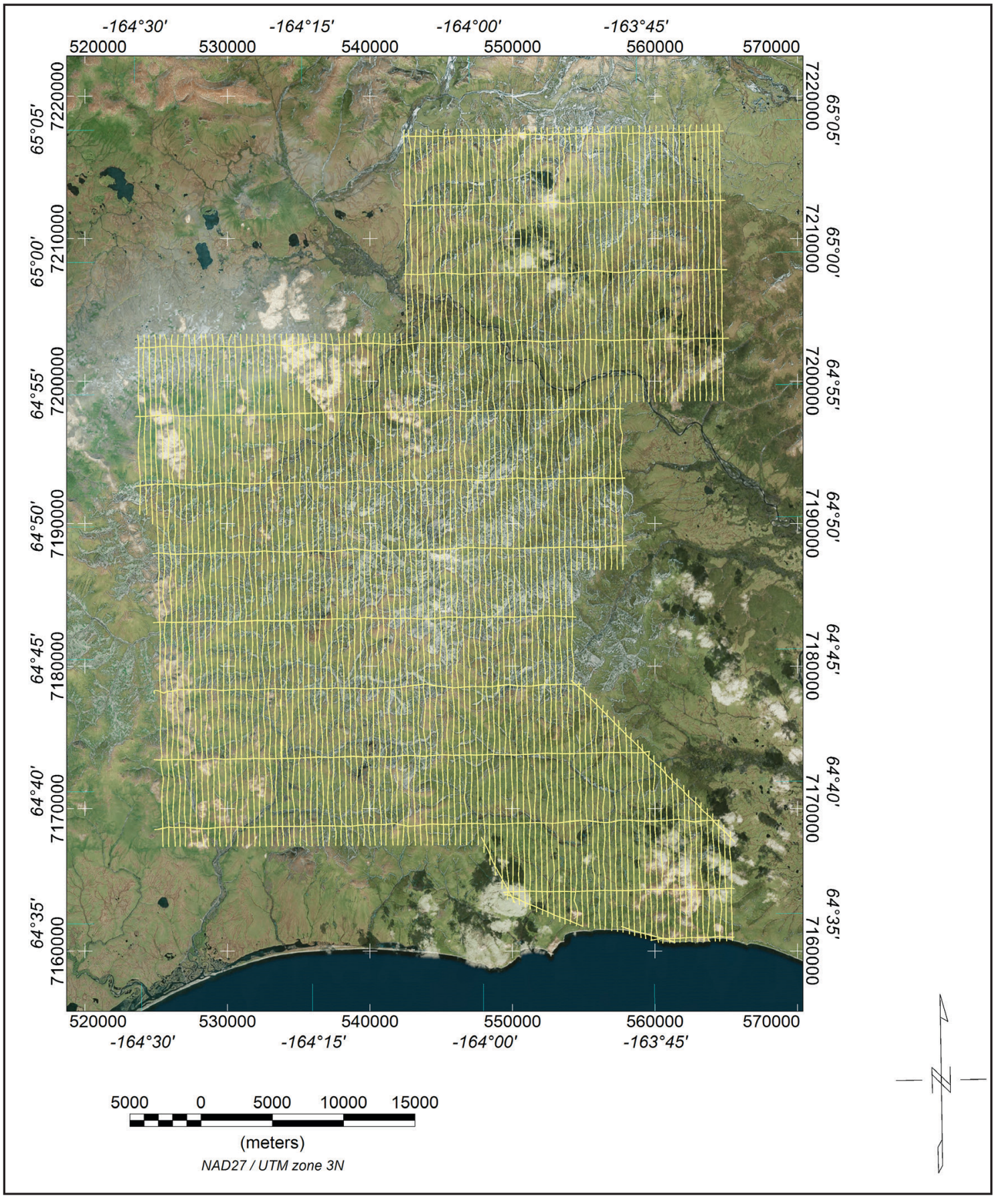

Figure 2. Flight path with orthometric image. 


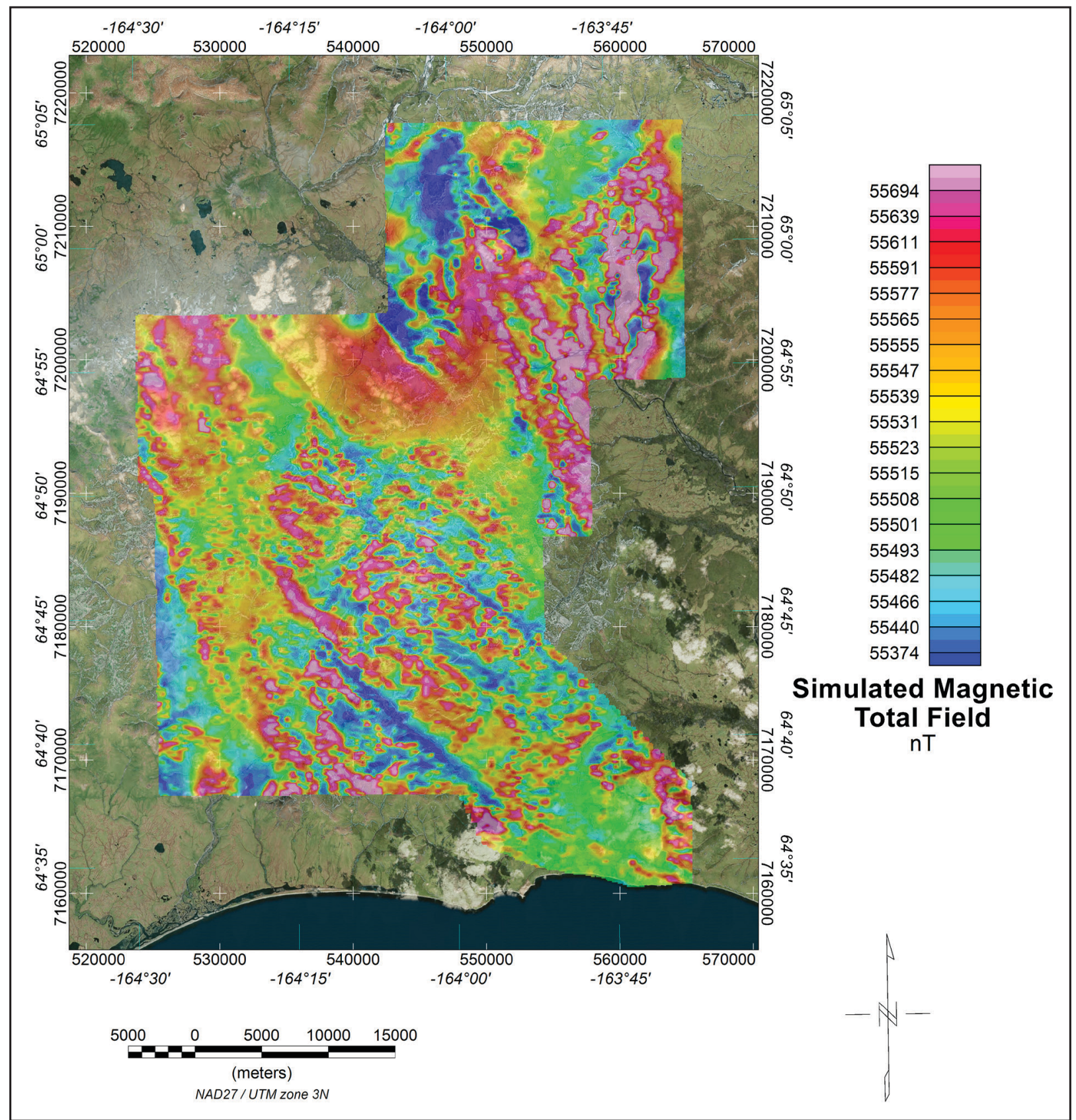

Figure 3. The simulated magnetic total field data were created using digitally recorded data from a Scintrex cesium magnetometer. Data were collected at a sampling interval of 0.1 seconds. The magnetic data were (1) corrected for diurnal variations by subtracting the digitally recorded base station magnetic data, (2) IGRF corrected (IGRF model 2000, updated to August 2002), updated for date of flight and altimeter variations), (3) leveled to the tie line data, (4) a constant value of approximately 55,000 nT was added to all data, and (5) interpolated onto a regular $100 \mathrm{~m}$ grid using a modified Akima (Akima 1970) technique. 


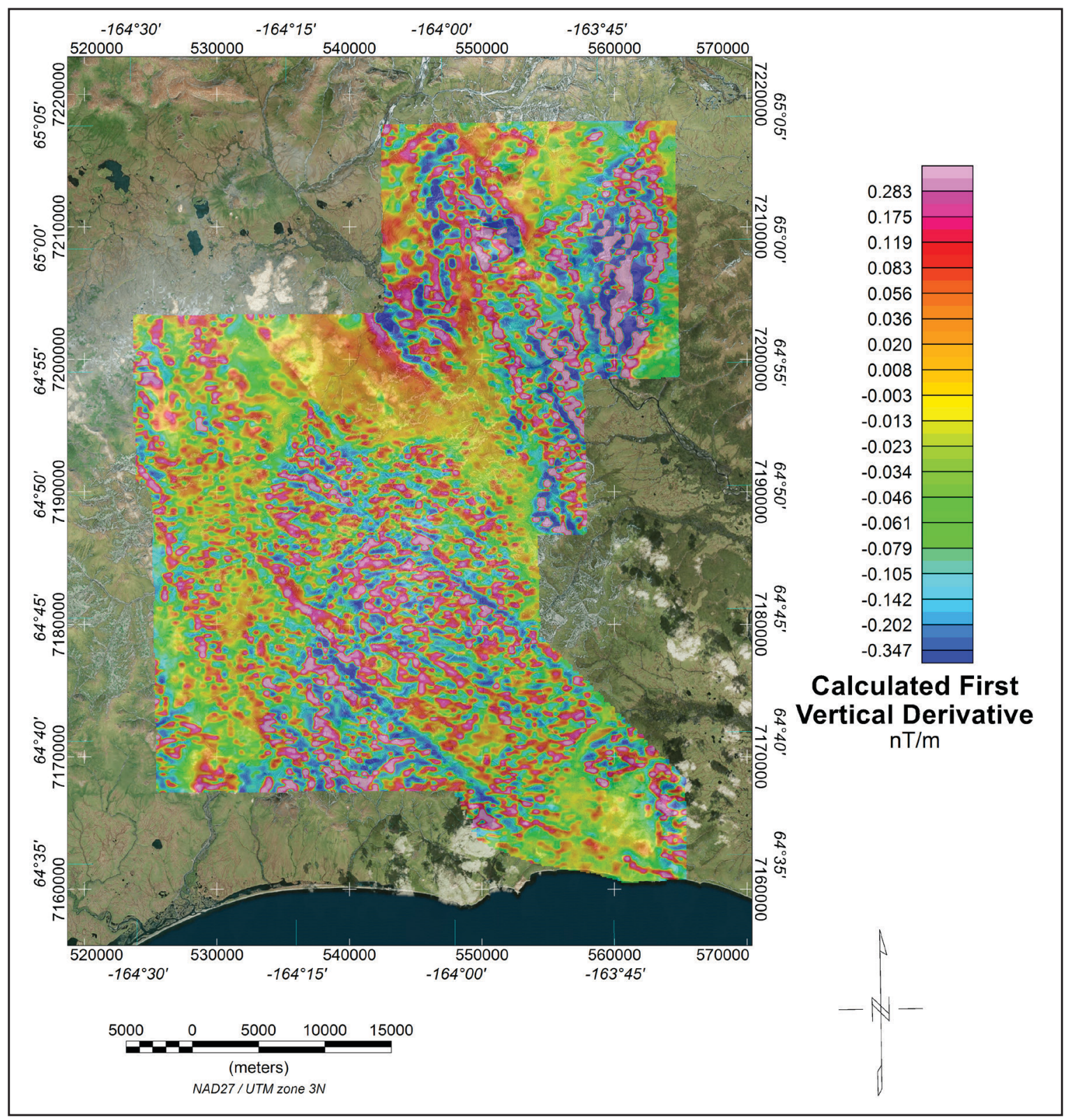

Figure 4. The calculated first vertical derivative data were created using digitally recorded data from a Scintrex cesium magnetometer. Data were collected at a sampling interval of 0.1 seconds. The magnetic data were (1) corrected for diurnal variations by subtraction of the digitally recorded base station magnetic data, (2) IGRF corrected (IGRF model 2000, updated August 2002), updated for date of flight and altimeter variations), (3) leveled to the tie line data, and (4) interpolated onto a regular $100 \mathrm{~m}$ grid using a modified Akima (1970) technique. The first vertical derivative grid was calculated from the processed total magnetic field grid using an FFT base frequency domain filtering algorithm. The resulting first vertical derivative grid provides better definition and resolution of near-surface magnetic units and helps to identify weak magnetic features that may not be evident on the total field data. 


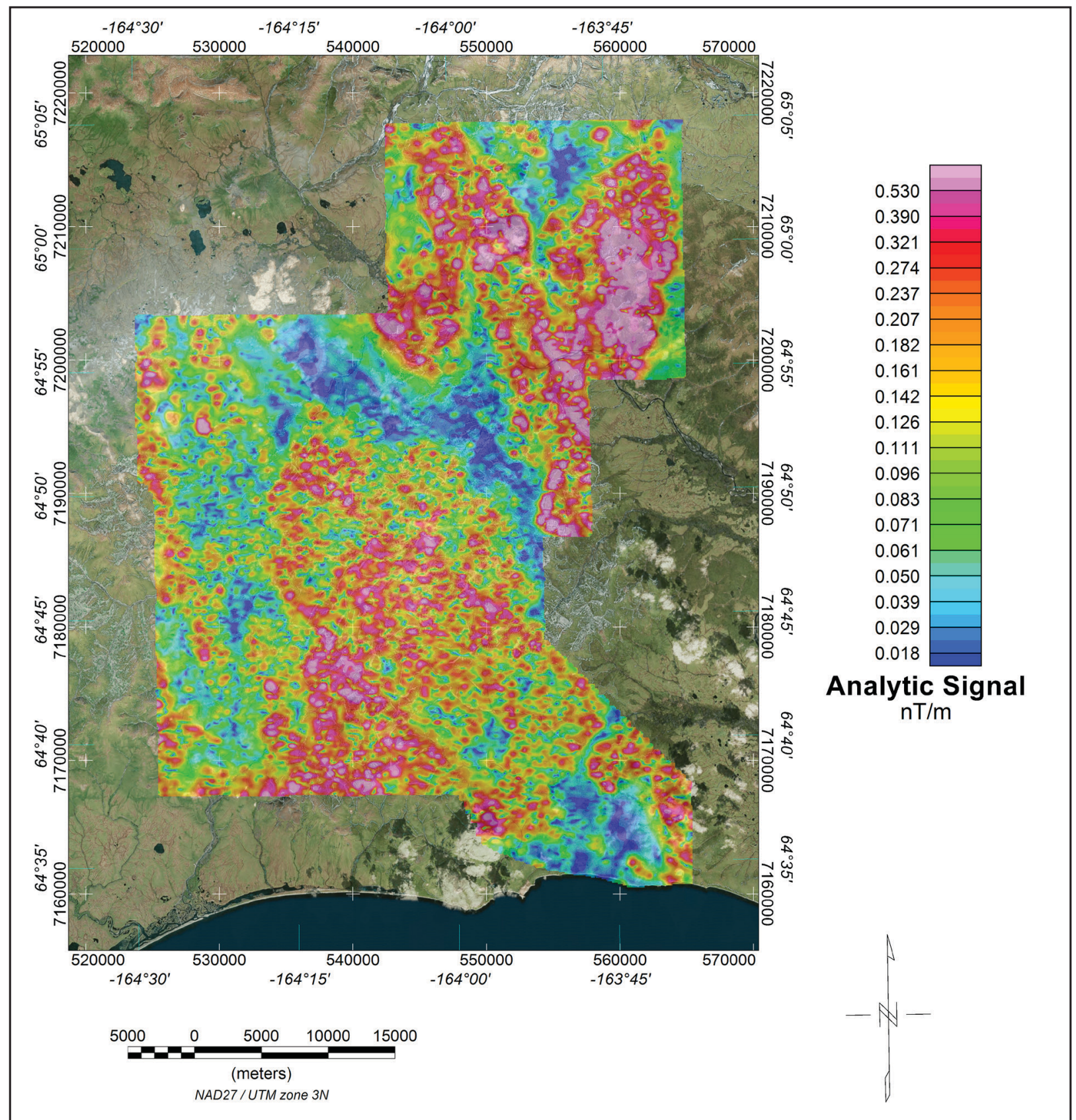

Figure 5. Analytic signal is the total amplitude of all directions of magnetic gradient calculated from the sum of the squares of the three orthogonal gradients. Mapped highs in the calculated analytic signal of magnetic parameter locate the anomalous source body edges and corners (such as contacts, fault/shear zones, etc.). Analytic signal maxima are located directly over faults and contacts, regardless of structural dip, and independent of the direction of the induced and/or remanent magnetizations. 


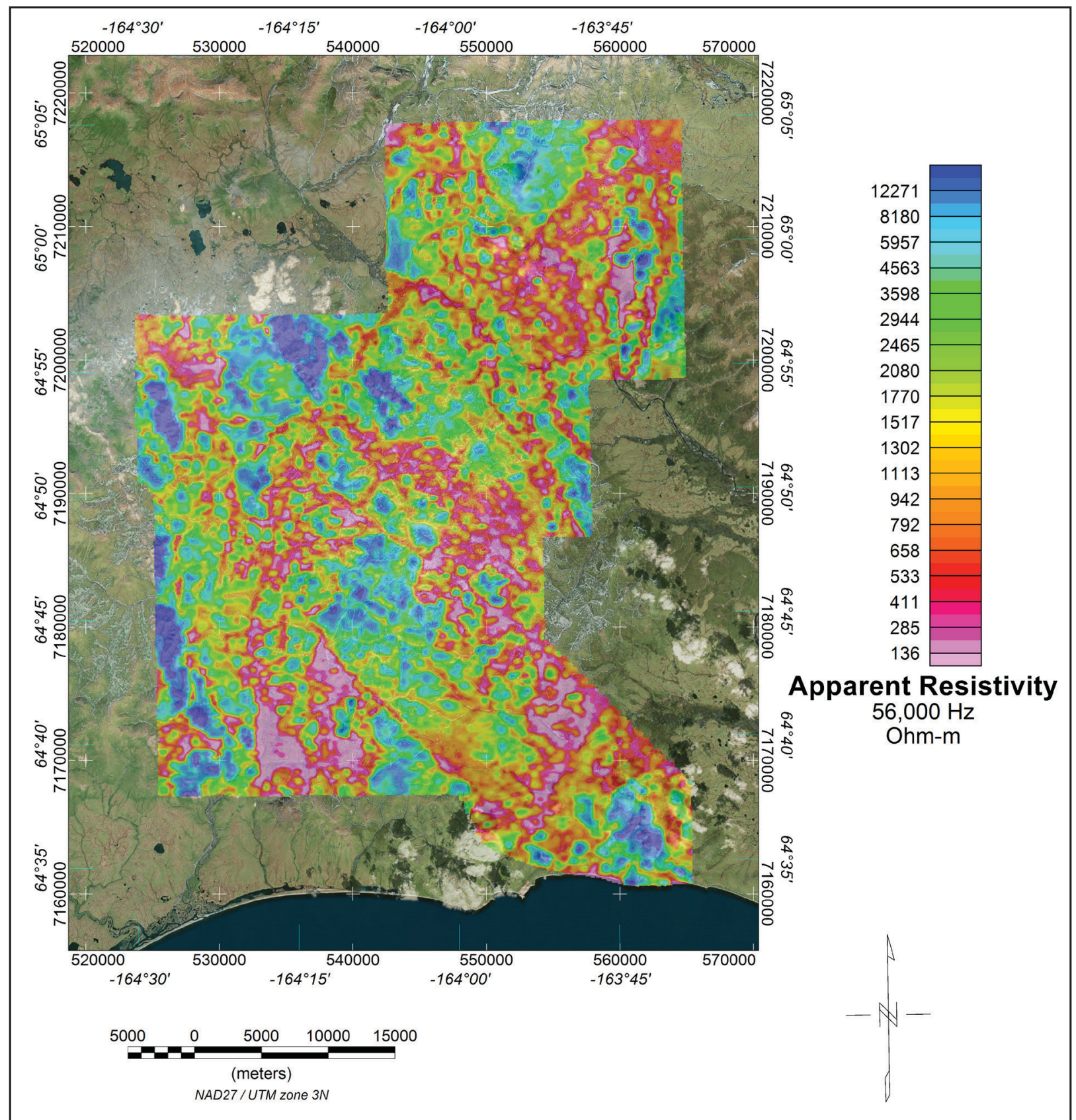

Figure 6. The DIGHEMV EM system measured inphase and quadrature components at five frequencies. Two vertical coaxial coil-pairs operated at 1000 and 5500 $\mathrm{Hz}$ while three horizontal coplanar coil-pairs operated at 900, 7,200 and 56,000 Hz. EM data were sampled at 0.1-second intervals. The EM system responds to bedrock conductors, conductive overburden, and cultural sources. Apparent resistivity is generated from the inphase and quadrature component of the coplanar $56,000 \mathrm{~Hz}$ using the pseudo-layer half-space model. The data were interpolated onto a regular $100 \mathrm{~m}$ grid using a modified Akima (Akima 1970) technique. 


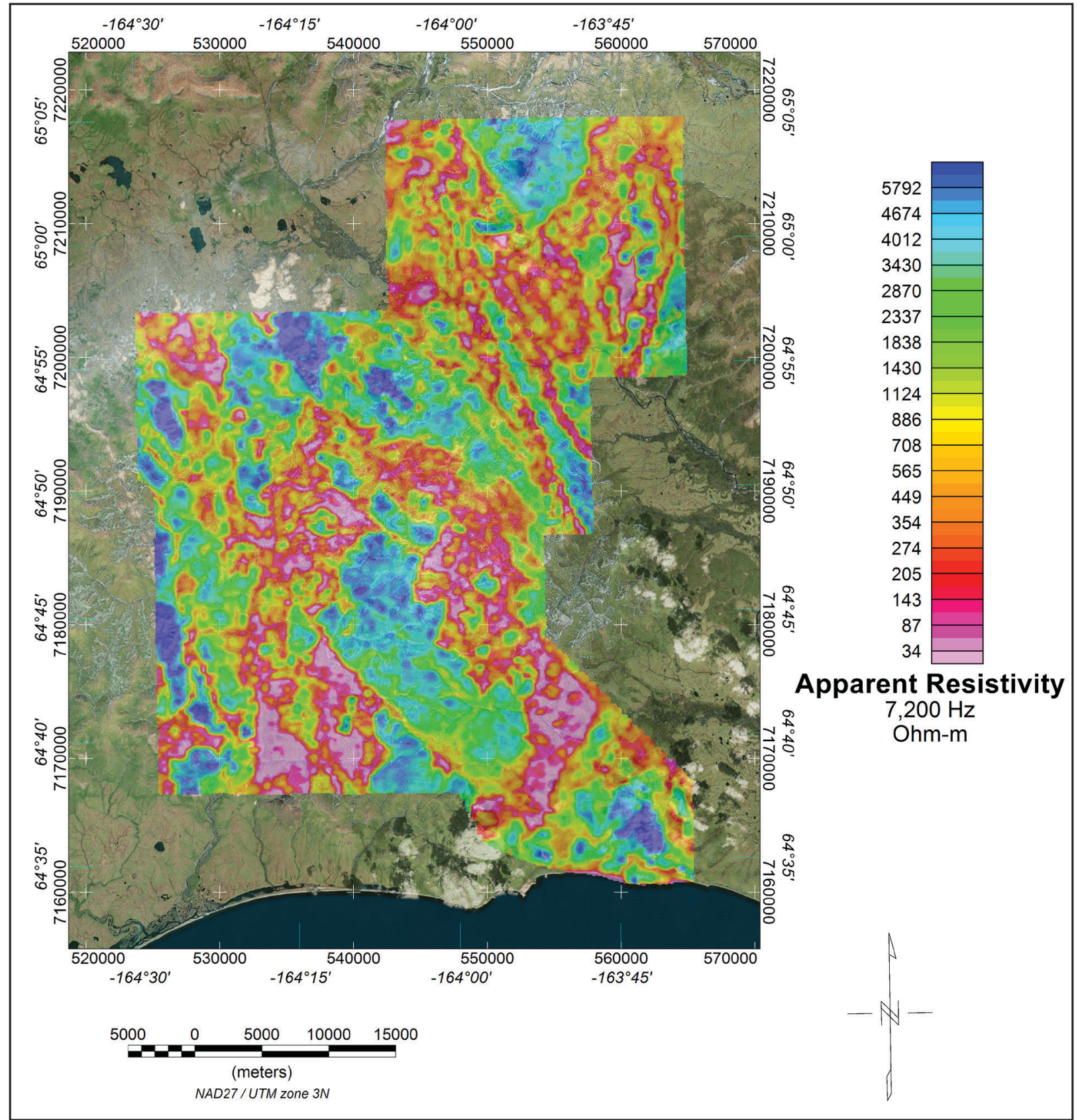

Figure 7. The DIGHEMV EM system measured inphase and quadrature components at five frequencies. Two vertical coaxial coil-pairs operated at 1000 and 5500 $\mathrm{Hz}$ while three horizontal coplanar coil-pairs operated at 900, 7,200 and 56,000 Hz. EM data were sampled at 0.1-second intervals. The EM system responds to bedrock conductors, conductive overburden, and cultural sources. Apparent resistivity is generated from the inphase and quadrature component of the coplanar $7,200 \mathrm{~Hz}$ using the pseudo-layer half-space model. The data were interpolated onto a regular $100 \mathrm{~m}$ grid using a modified Akima (Akima 1970) technique. 


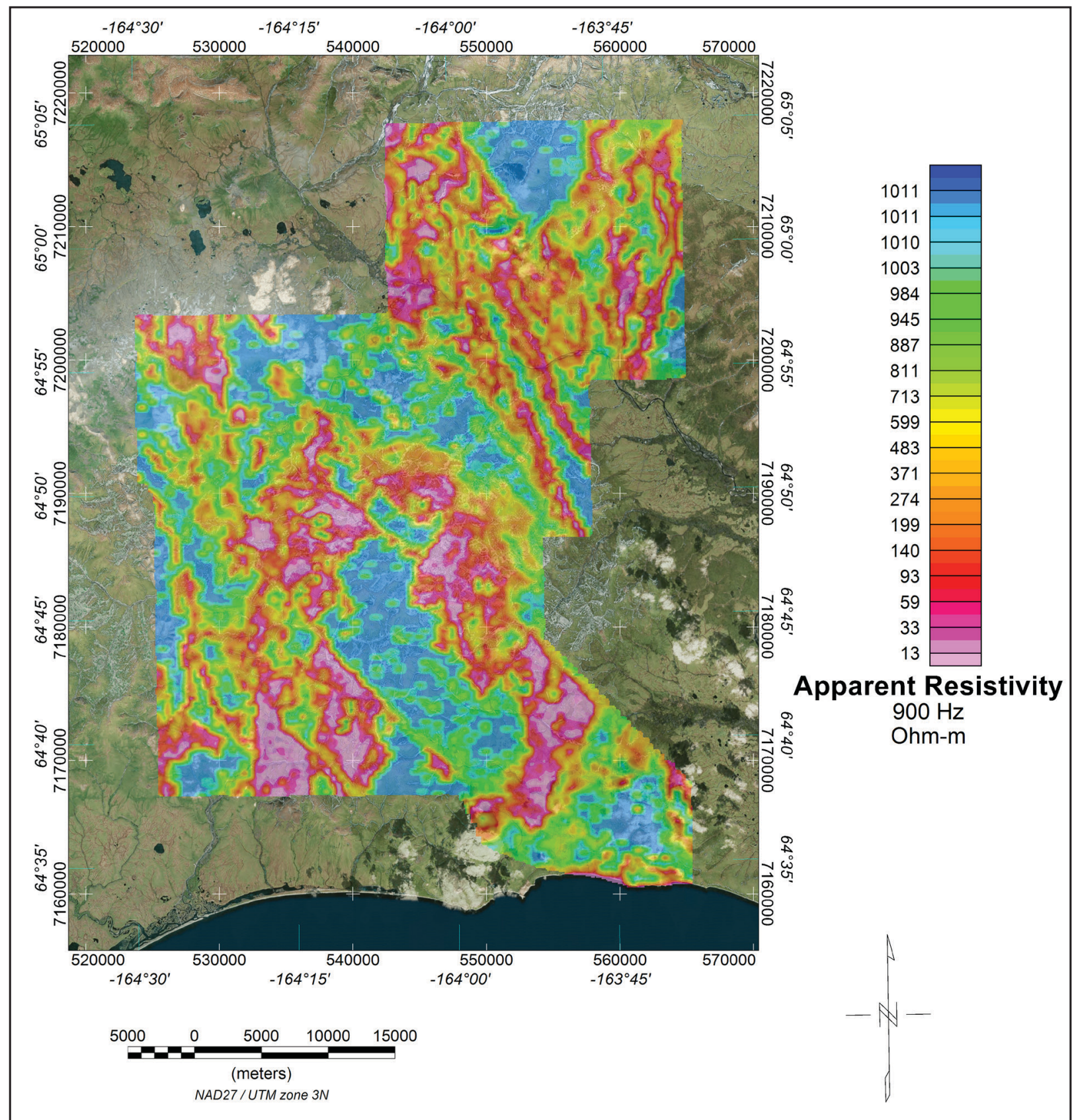

Figure 8. The DIGHEMV EM system measured inphase and quadrature components at five frequencies. Two vertical coaxial coil-pairs operated at 1000 and 5500 $\mathrm{Hz}$ while three horizontal coplanar coil-pairs operated at 900, 7,200 and 56,000 Hz. EM data were sampled at 0.1-second intervals. The EM system responds to bedrock conductors, conductive overburden, and cultural sources. Apparent resistivity is generated from the inphase and quadrature component of the coplanar $900 \mathrm{~Hz}$ using the pseudo-layer half-space model. The data were interpolated onto a regular $100 \mathrm{~m}$ grid using a modified Akima (Akima 1970) technique. 
Table 1. Copies of the following maps are included at the end of this booklet. The low-resolution, page-size maps included in this booklet are intended to be used as a search tool and are not the final product. Large-scale, full-resolution versions of each map are available to download on this publication's citation page: $\underline{\text { http://doi.org/10.14509/30172. }}$

\begin{tabular}{|c|c|}
\hline Map Title & Description \\
\hline council_sim_magtf_topo_map_1 of2.pdf & simulated magnetic total field grid with topographic base map \\
\hline council_sim_magtf_topo_map_2of2.pdf & simulated magnetic total field grid with topographic base map \\
\hline council_sim_magtf_contours_plss_map_2of2.pdf & simulated magnetic total field grid and contours with public land survey system base layer \\
\hline council_sim_magtf_shaded_plss_map_1 of2.pdf & shaded simulated magnetic total field grid with public land survey system base layer \\
\hline council_sim_magtf_shaded_plss_map_2of2.pdf & shaded simulated magnetic total field grid with public land survey system base layer \\
\hline council_em_anomalies_sim_magtf_contours_plss_map_1 of2.pdf & EM anomaly map with simulated magnetic total field grid contours and public land survey system base layer \\
\hline council_em_anomalies_sim_magtf_contours_plss_map_2of2.pdf & EM anomaly map with simulated magnetic total field grid contours and public land survey system base layer \\
\hline council_em_anomalies_sim_magtf_contours_detailed_topo_map_1 of6.pdf & EM anomaly map with simulated magnetic total field grid contours and topographic base map \\
\hline council_em_anomalies_sim_magtf_contours_detailed_topo_map_2of6.pdf & EM anomaly map with simulated magnetic total field grid contours and topographic base map \\
\hline council_em_anomalies_sim_magtf_contours_detailed_topo_map_3of6.pdf & EM anomaly map with simulated magnetic total field grid contours and topographic base map \\
\hline council_em_anomalies_sim_magtf_contours_detailed_topo_map_4of6.pdf & EM anomaly map with simulated magnetic total field grid contours and topographic base map \\
\hline council_em_anomalies_sim_magtf_contours_detailed_topo_map_5of6.pdf & EM anomaly map with simulated magnetic total field grid contours and topographic base map \\
\hline council_res7200hz_topo_map_1of2.pdf & $7,200 \mathrm{~Hz}$ apparent resistivity grid with topographic base map \\
\hline council_res7200hz_topo_map_2of2.pdf & $7,200 \mathrm{~Hz}$ apparent resistivity grid with topographic base map \\
\hline council_res7200hz_contours_plss_map_1 of2.pdf & $7,200 \mathrm{~Hz}$ apparent resistivity grid with contours and public land survey system base layer \\
\hline council_res7200hz_contours_plss_map_2of2.pdf & $7,200 \mathrm{~Hz}$ apparent resistivity grid with contours and public land survey system base layer \\
\hline council_res7200hz_contours_bw_plss_map_1of2.pdf & black and white $7,200 \mathrm{~Hz}$ apparent resistivity grid with contours and public land survey system base layer \\
\hline council_res7200hz_contours_bw_plss_map_2of2.pdf & black and white $7,200 \mathrm{~Hz}$ apparent resistivity grid with contours and public land survey system base layer \\
\hline council_res900hz_topo_map_1of2.pdf & $900 \mathrm{~Hz}$ apparent resistivity grid with topographic base map \\
\hline council_res900hz_topo_map_2of2.pdf & $900 \mathrm{~Hz}$ apparent resistivity grid with topographic base map \\
\hline council_res900hz_contours_plss_map_1 of2.pdf & $900 \mathrm{~Hz}$ apparent resistivity grid with contours and public land survey system base layer \\
\hline council_res900hz_contours_plss_map_2of2.pdf & $900 \mathrm{~Hz}$ apparent resistivity grid with contours and public land survey system base layer \\
\hline council_res900hz_contours_bw_plss_map_1 of2.pdf & black and white $900 \mathrm{~Hz}$ apparent resistivity grid with contours and public land survey system base layer \\
\hline council_res900hz_contours_bw_plss_map_2of2.pdf & black and white $900 \mathrm{~Hz}$ apparent resistivity grid with contours and public land survey system base layer \\
\hline council_flightlines_topo_map_1of2.pdf & flight lines with public land survey system base layer \\
\hline council_dem_plss_map_2of2.pdf & digital elevation model with public land survey system base layer \\
\hline council_interpretation_plss_map_1of2.pdf & interpretation based on geophysical data with public land survey system base layer \\
\hline council_interpretation_plss_map_2of2.pdf & interpretation based on geophysical data with public land survey system base layer \\
\hline
\end{tabular}




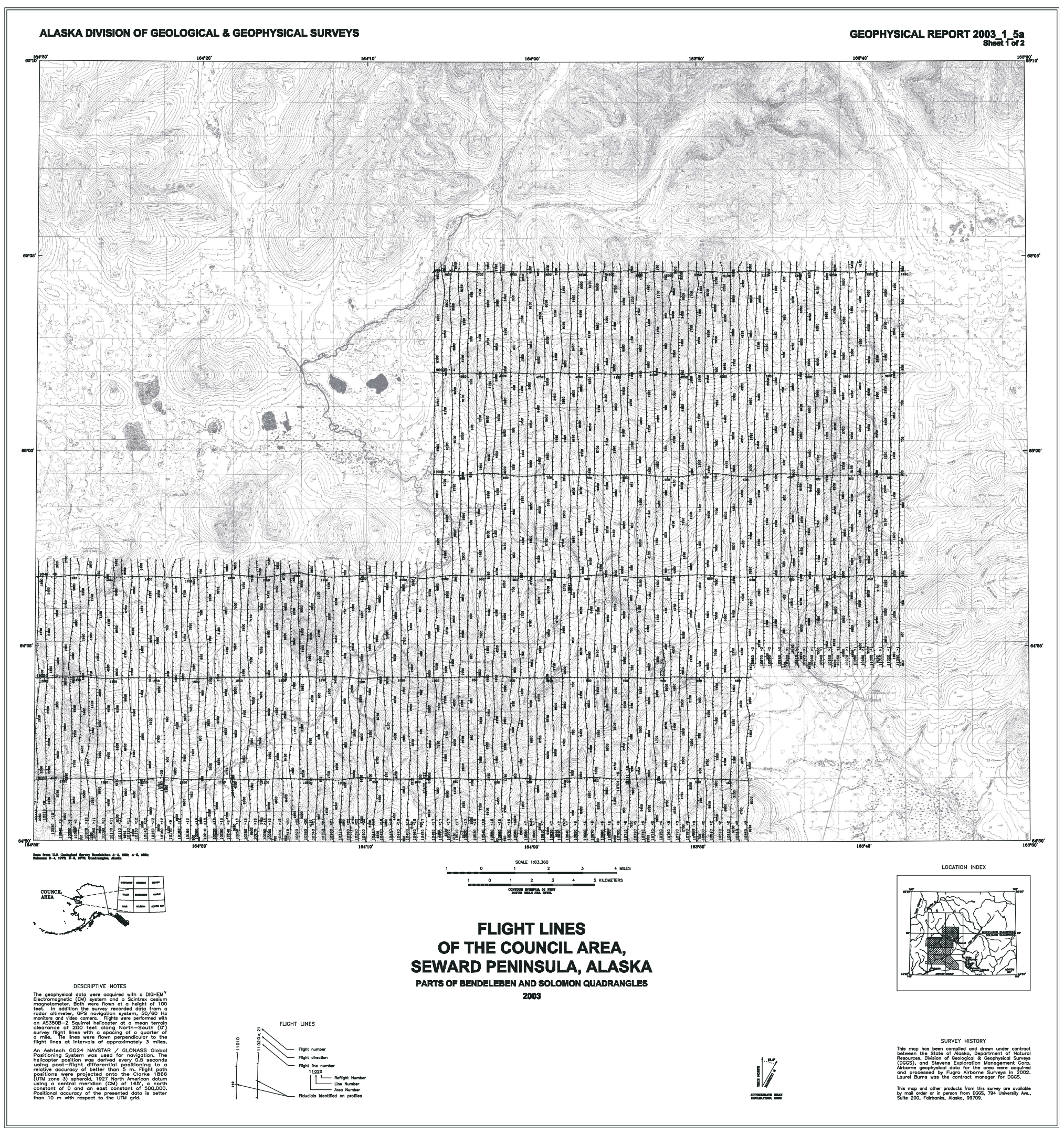




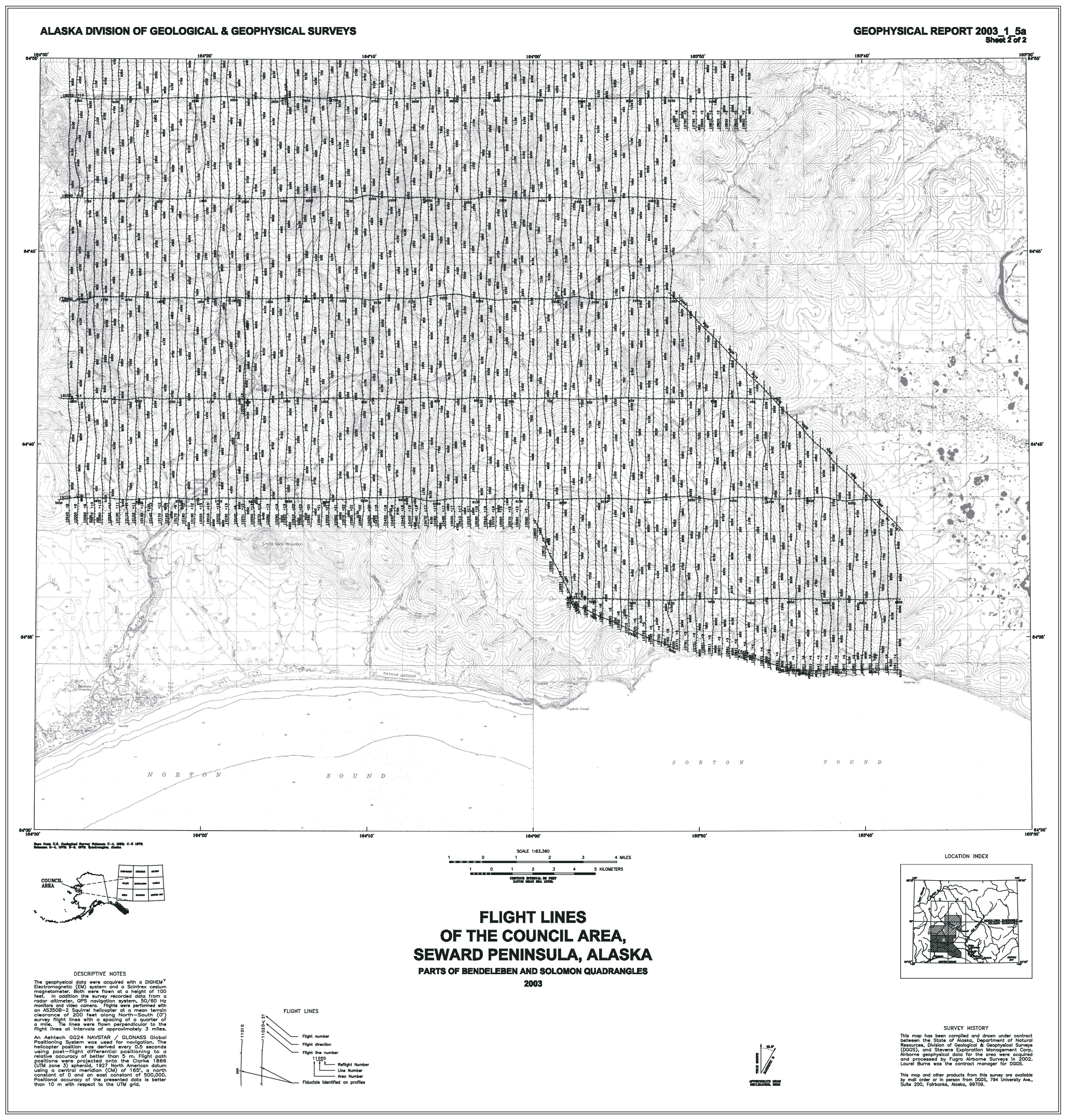




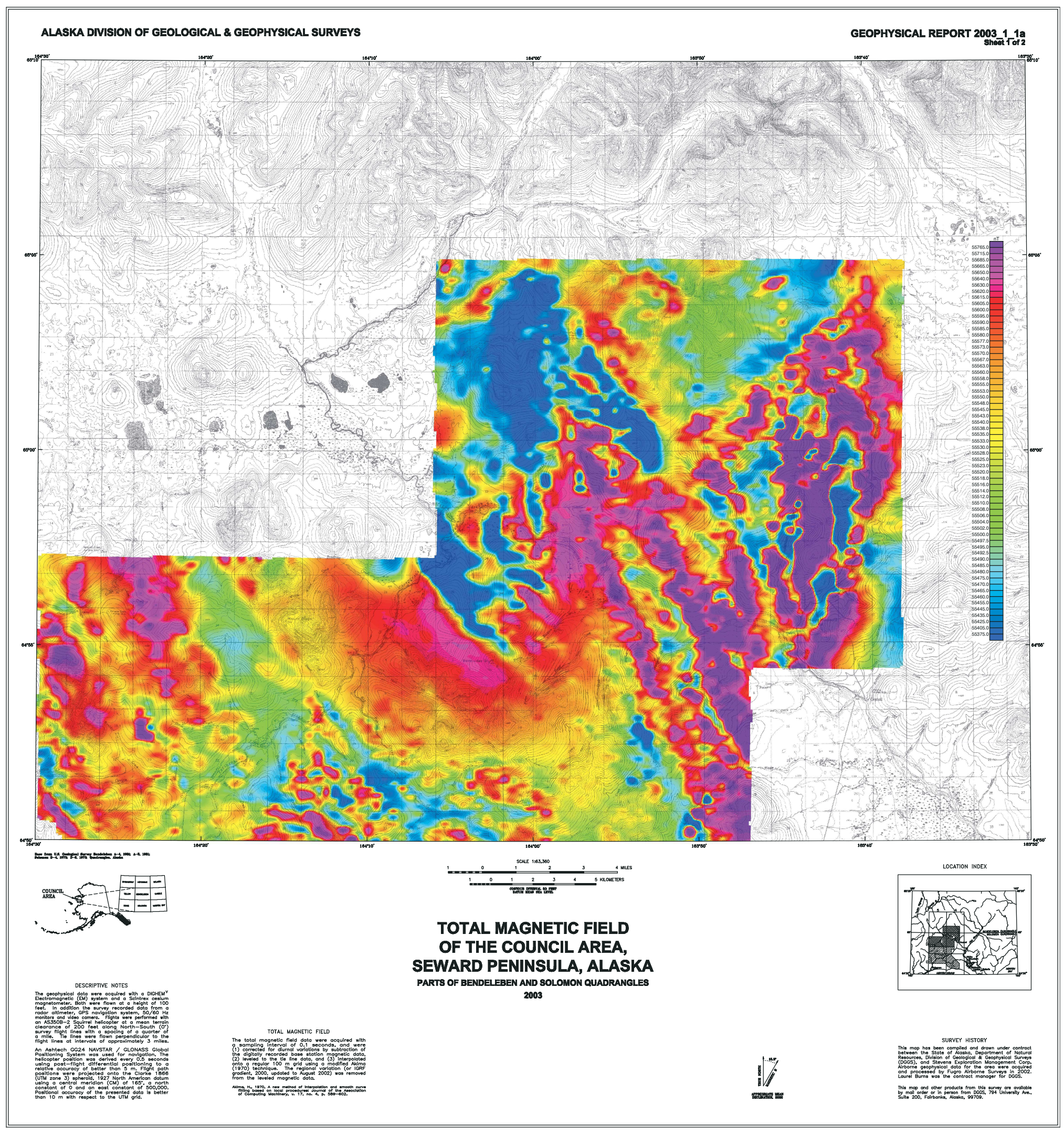




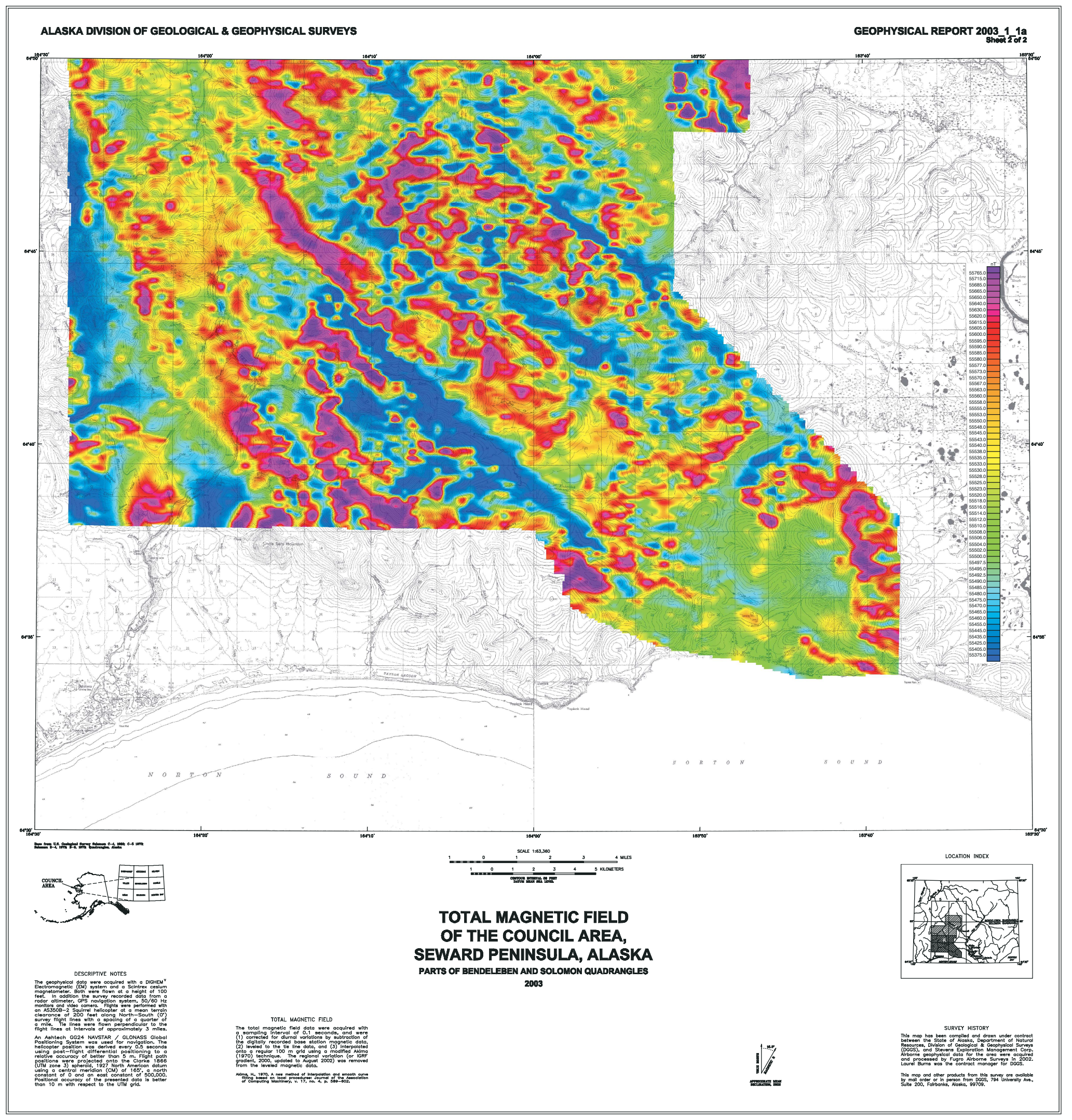




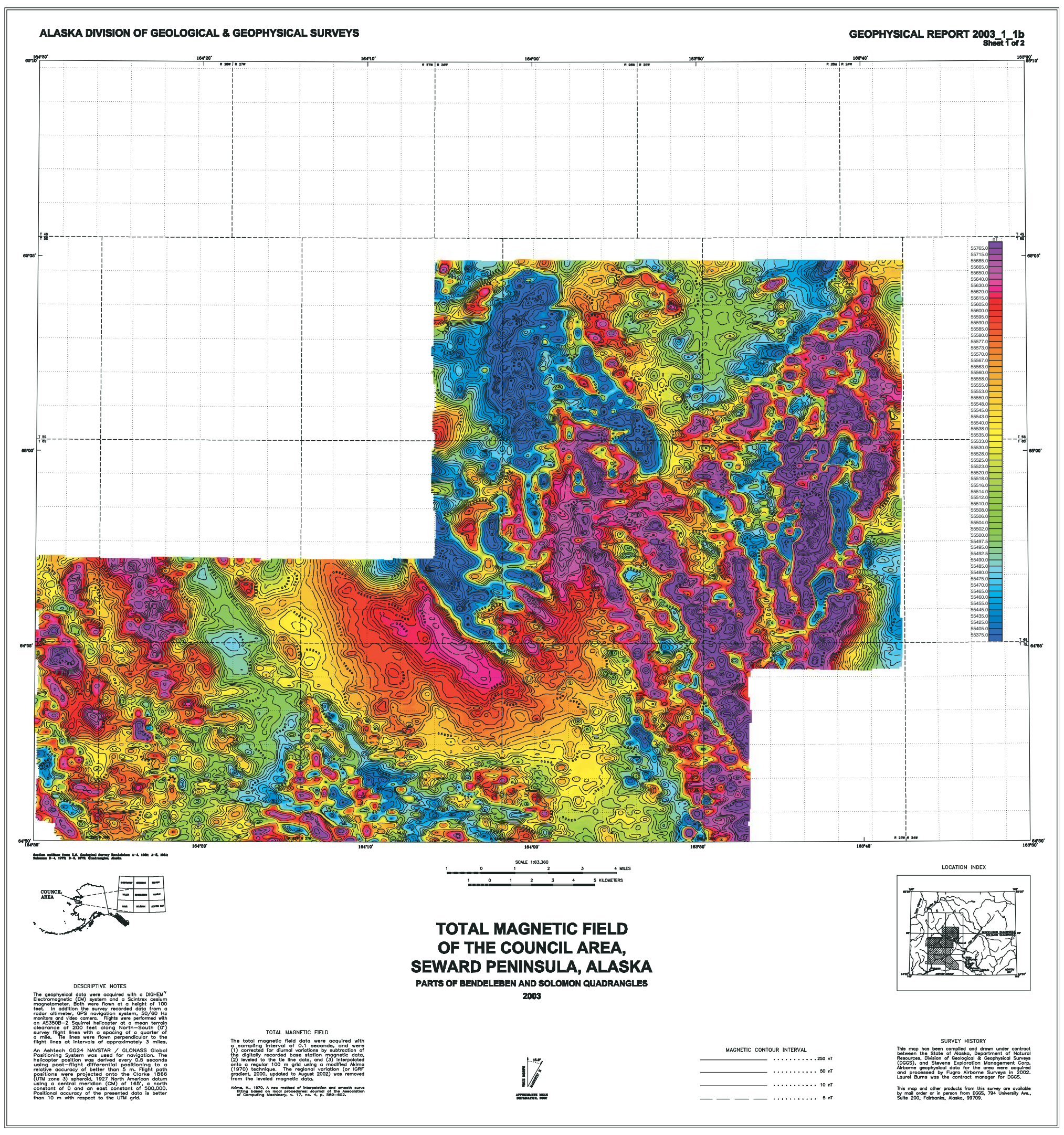




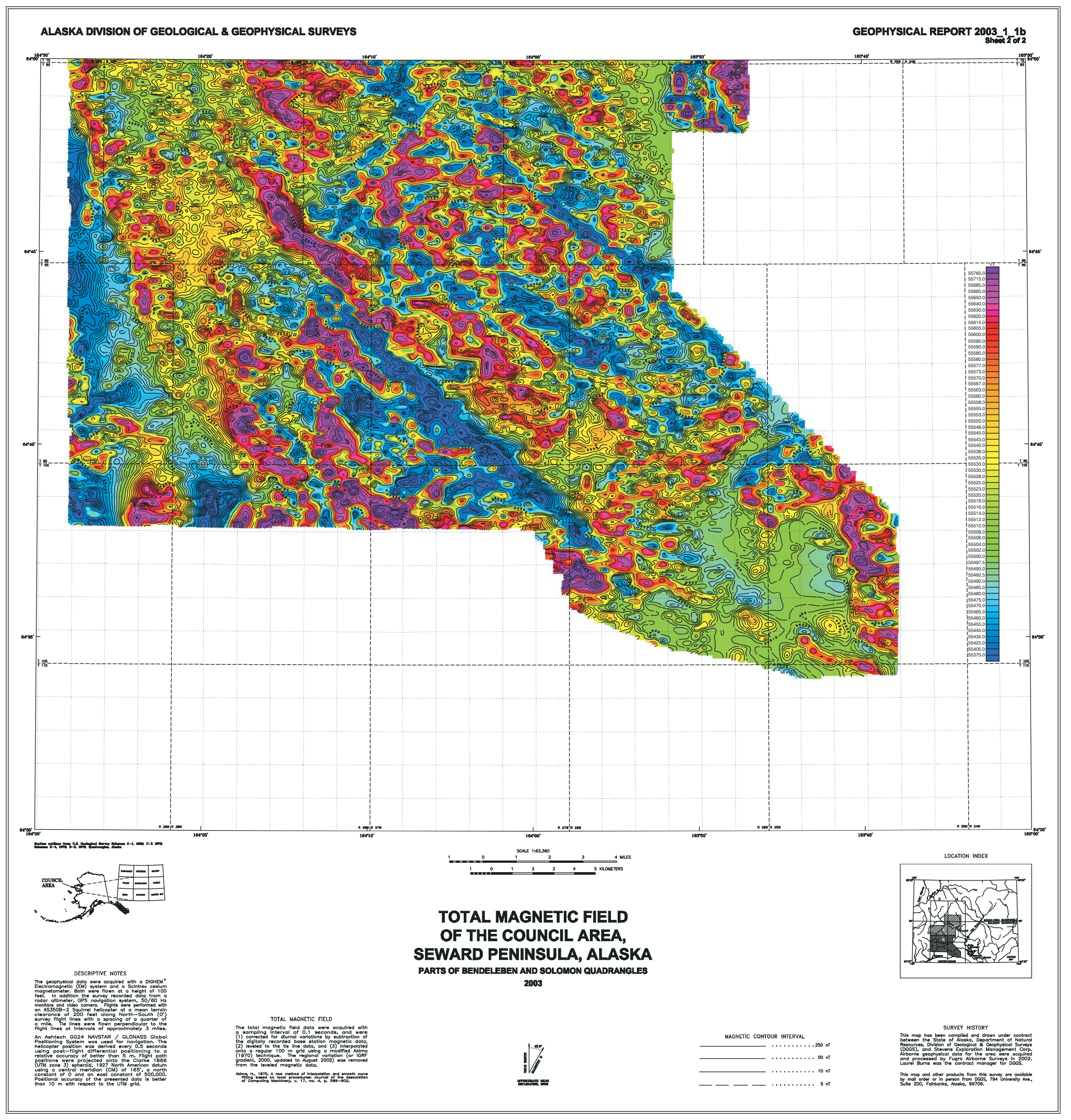




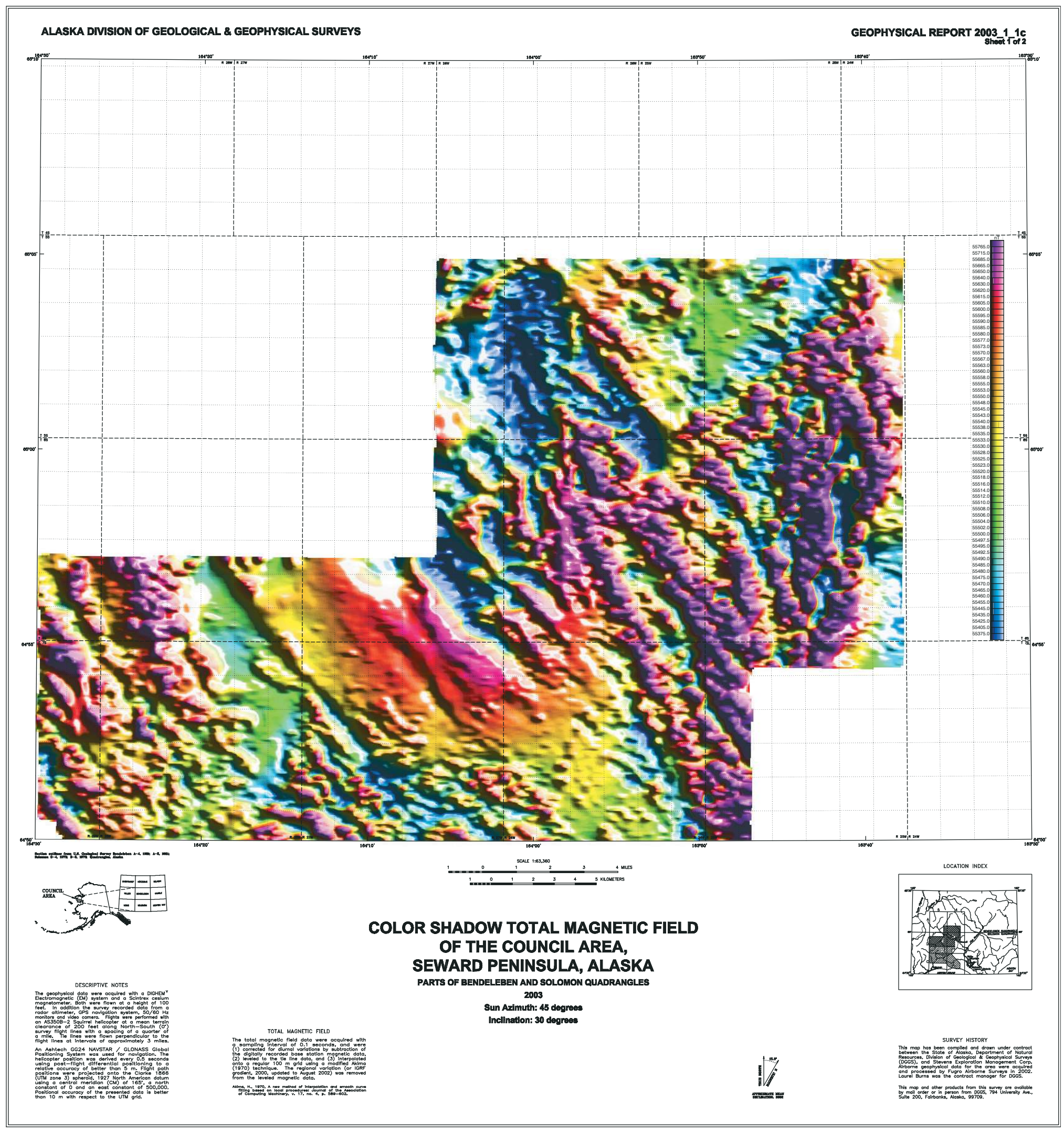




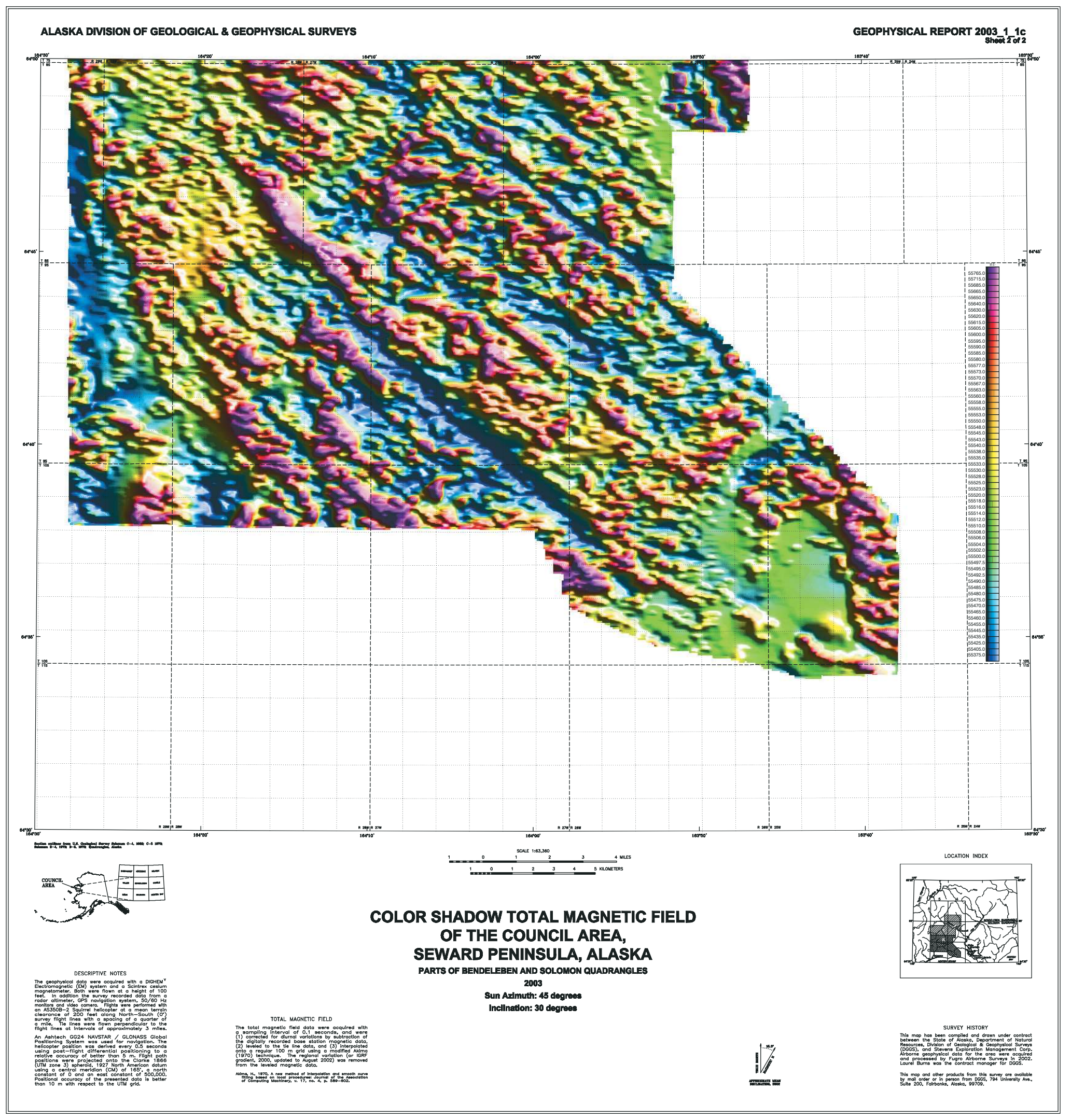




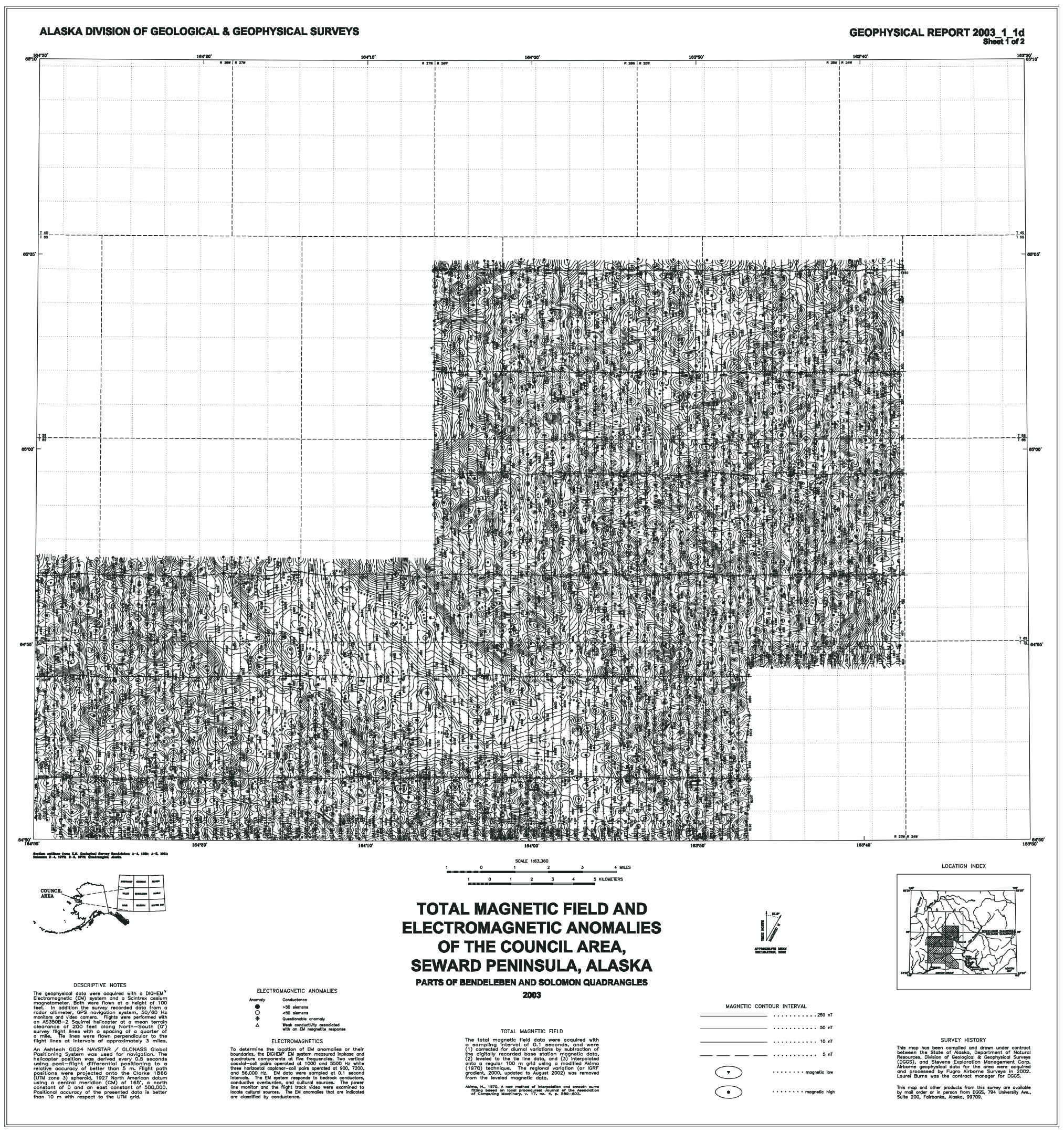




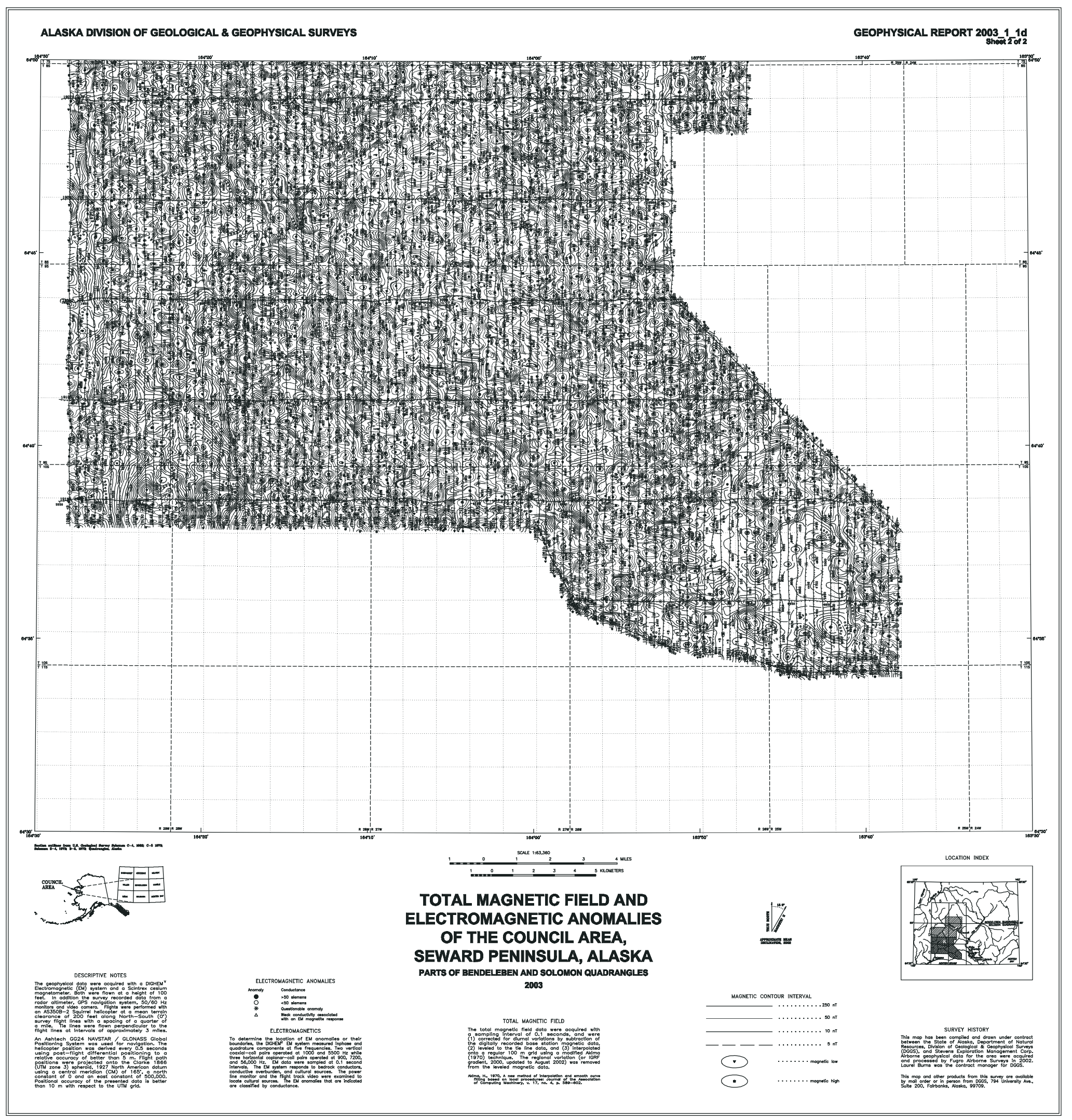




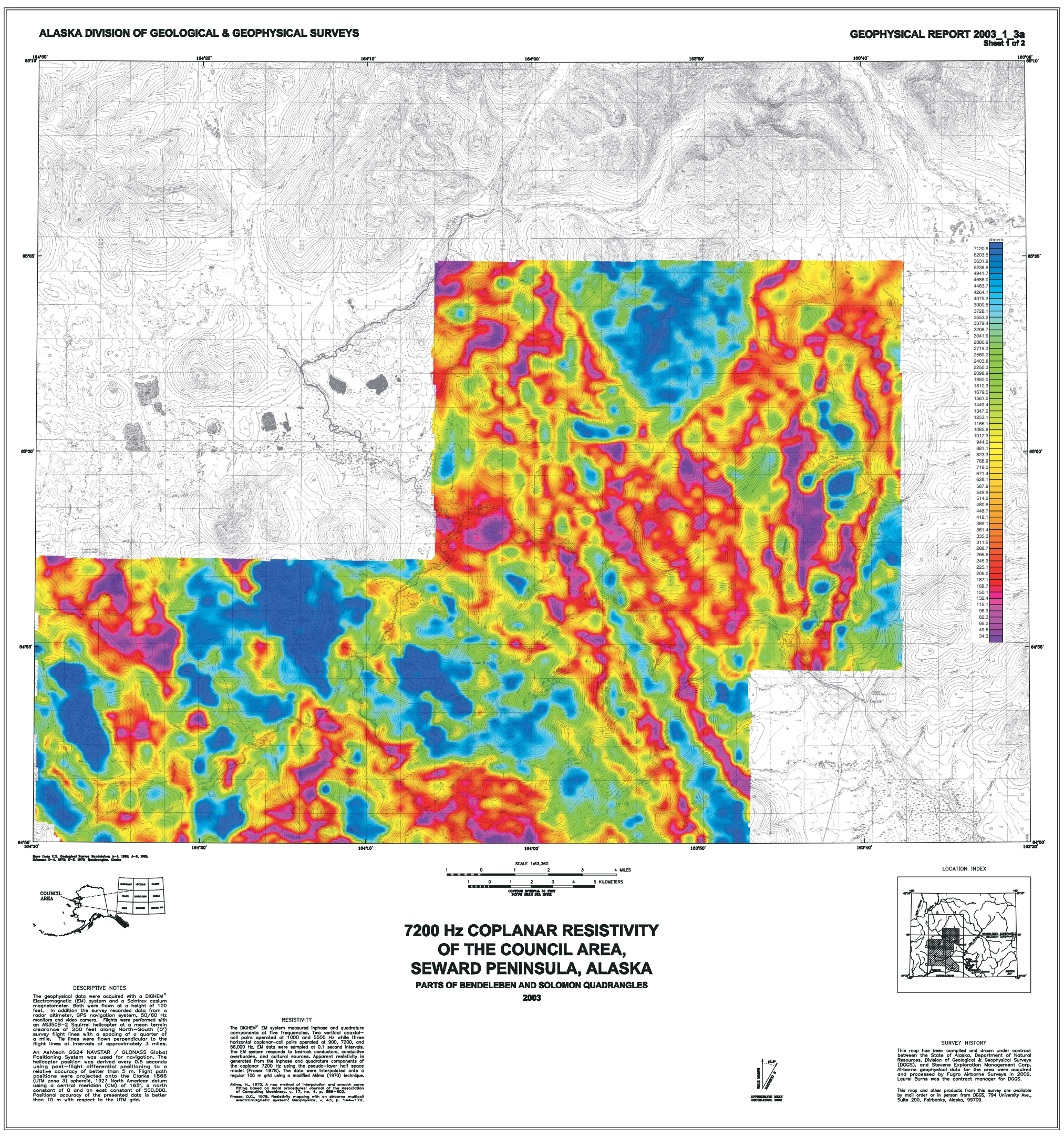




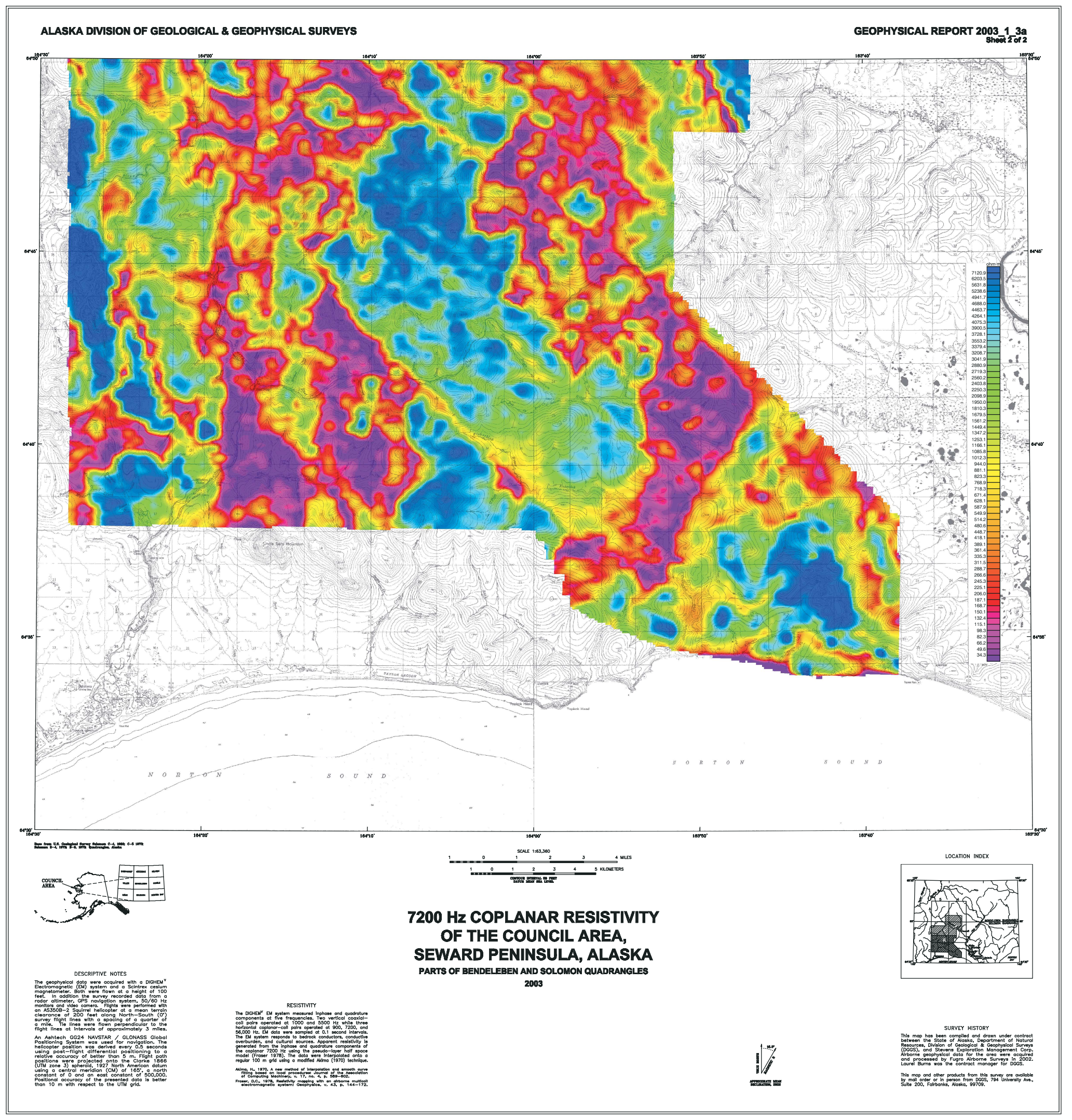




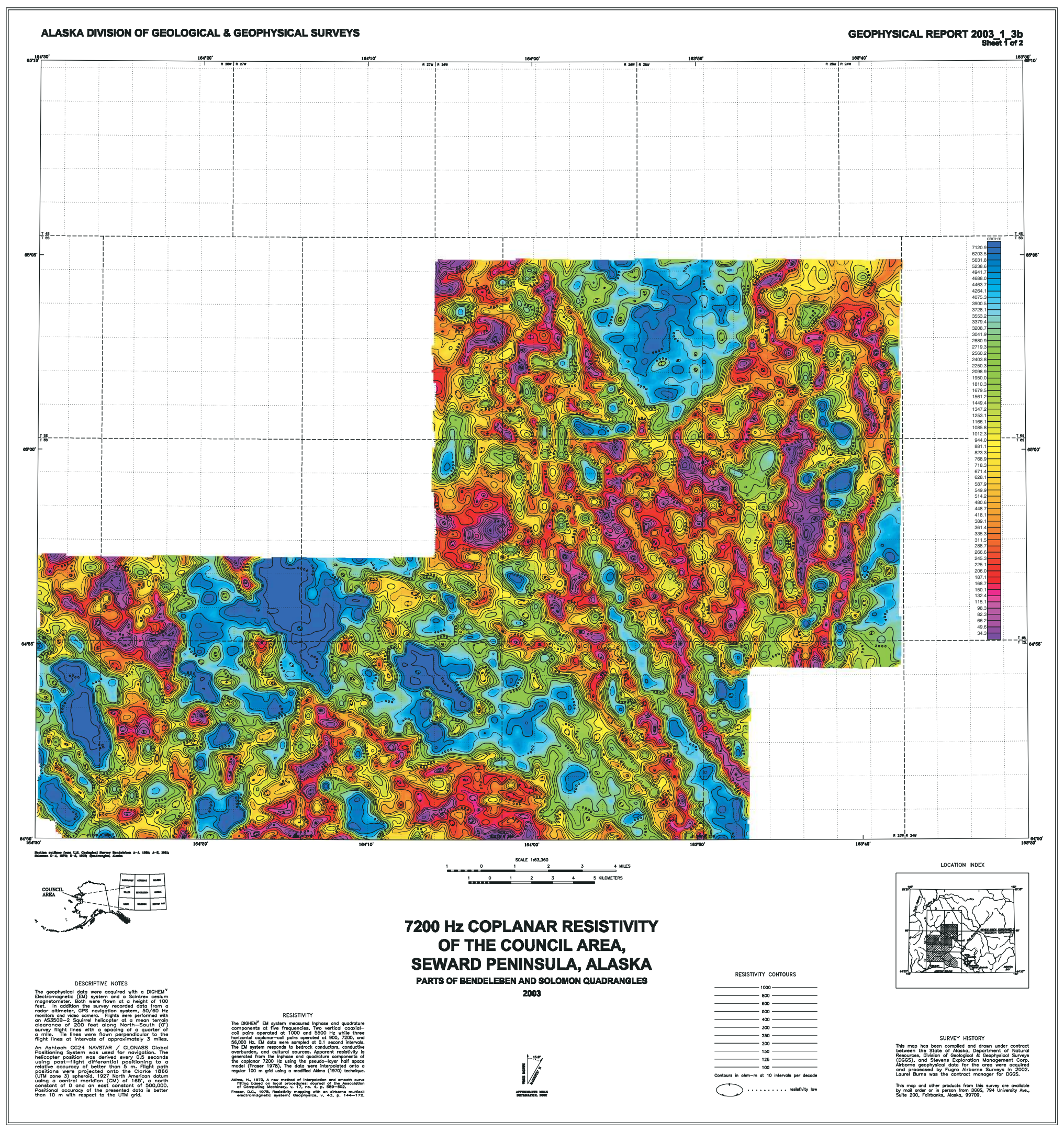




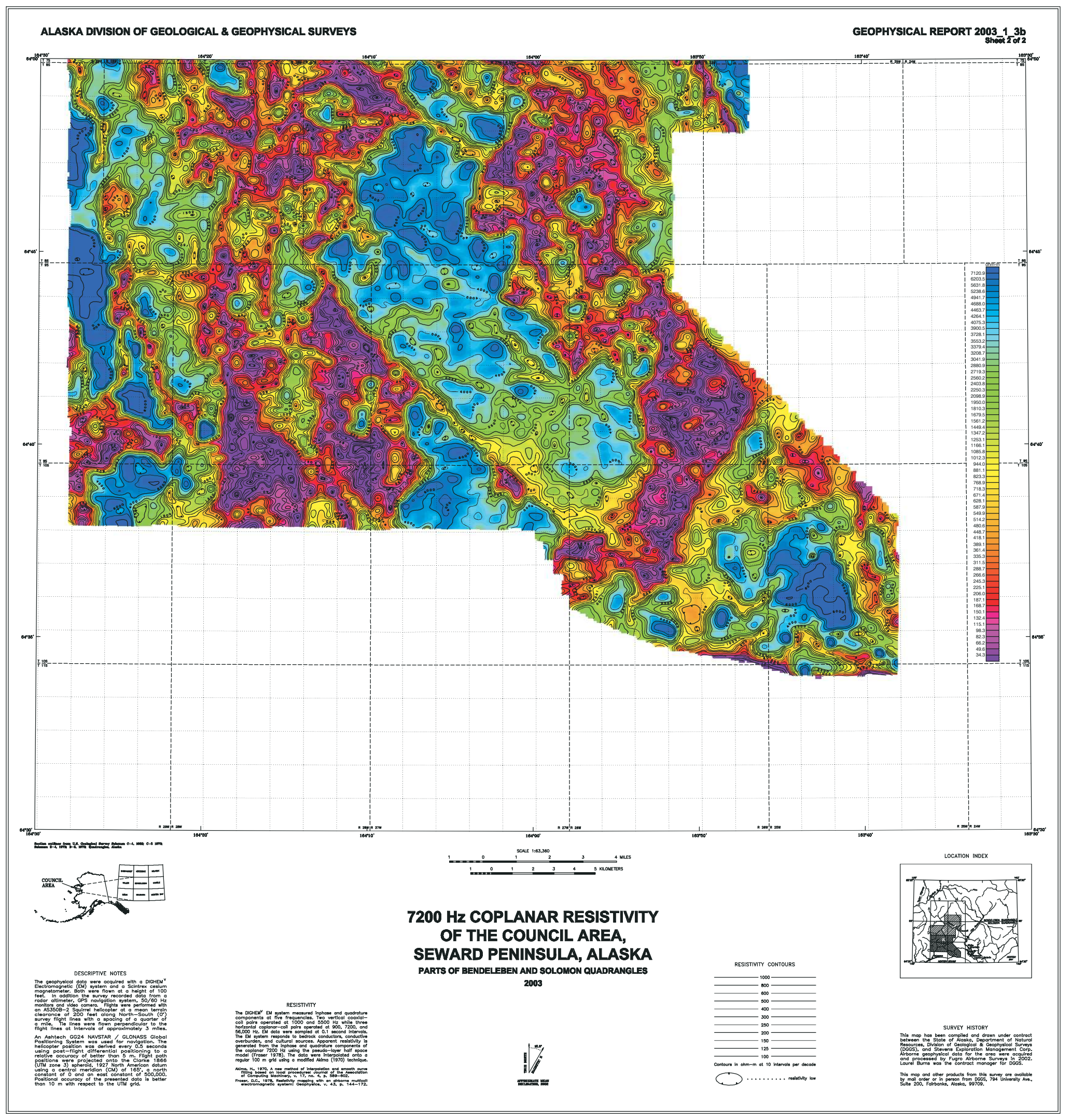




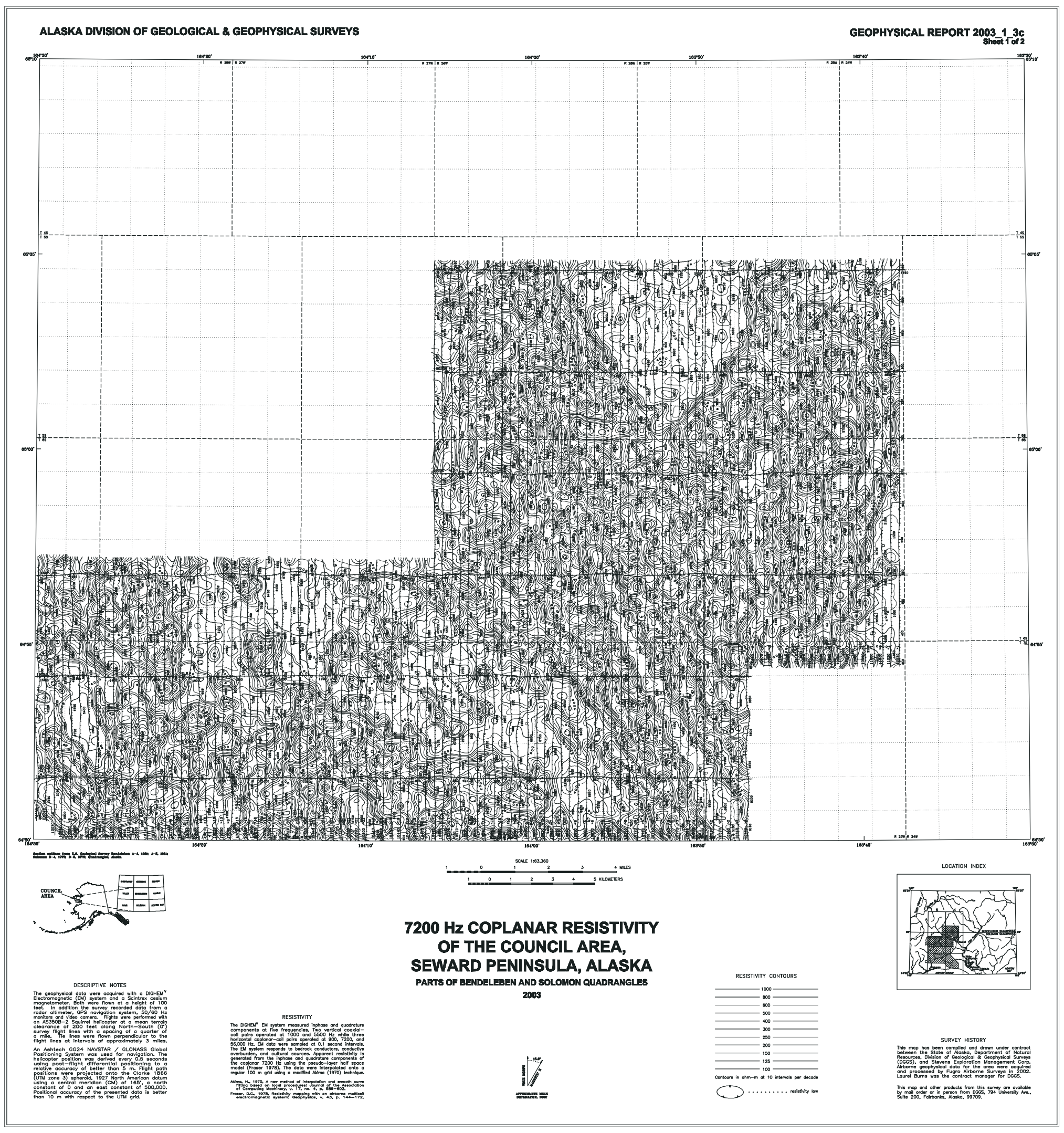









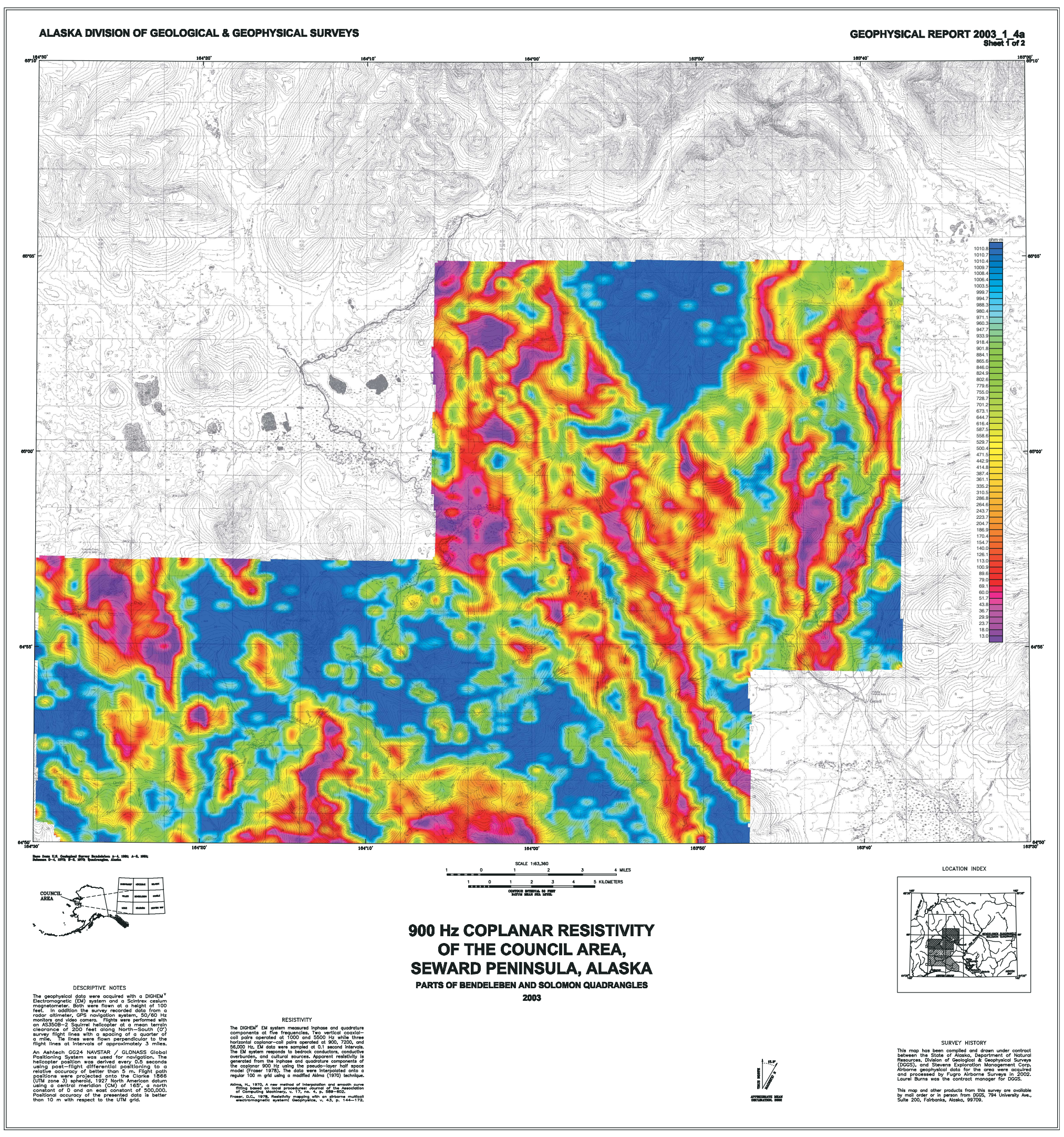




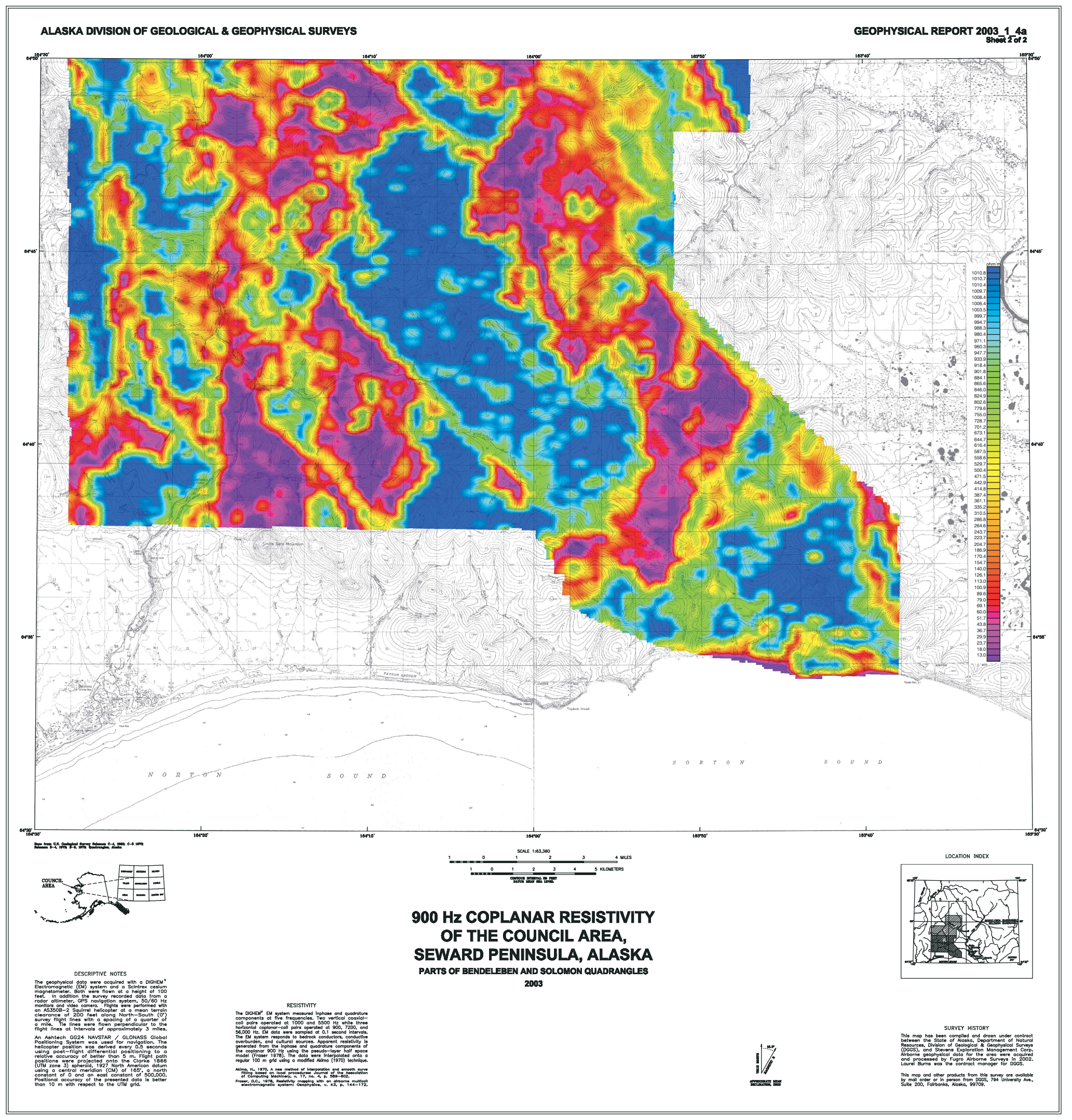




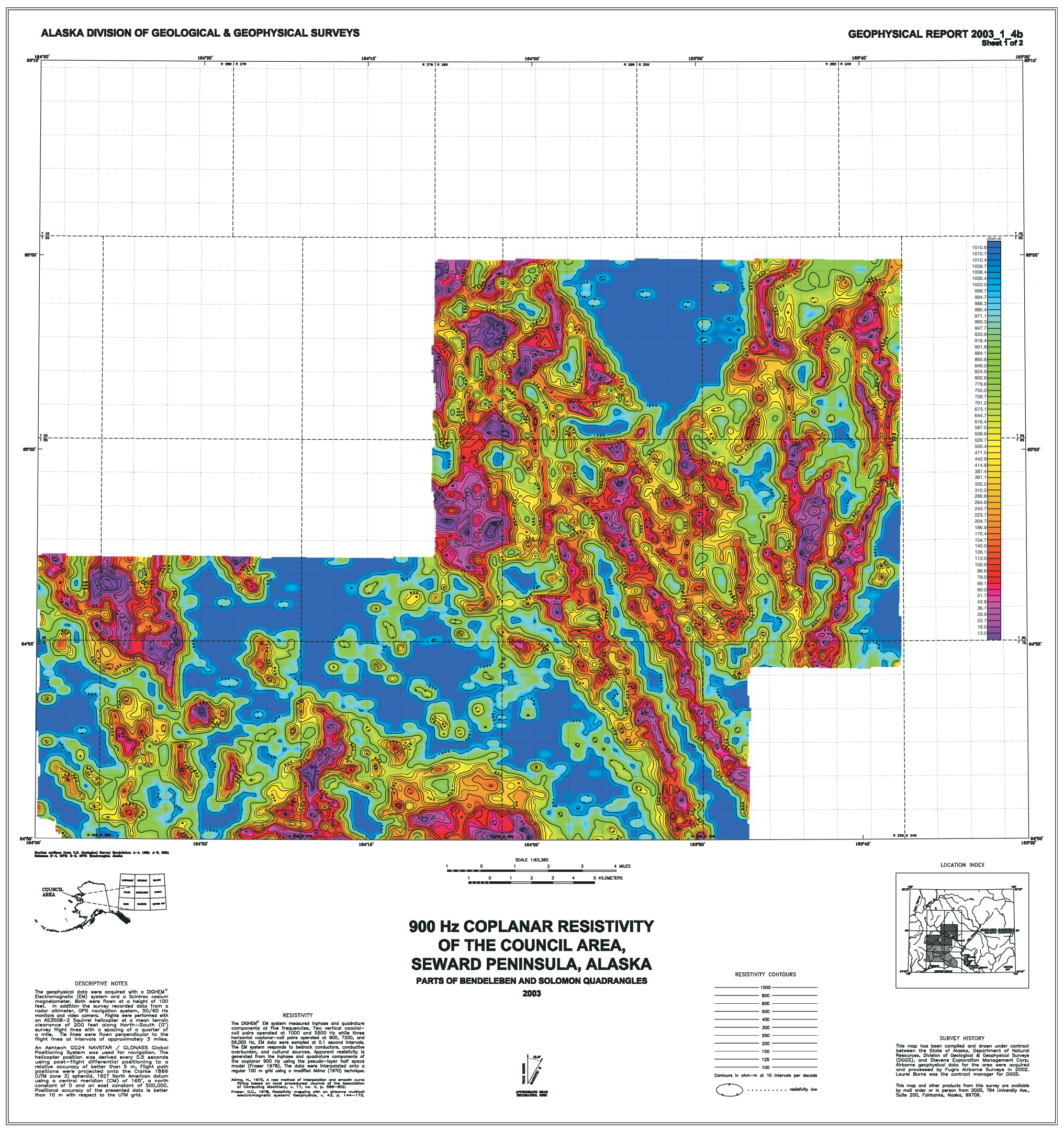




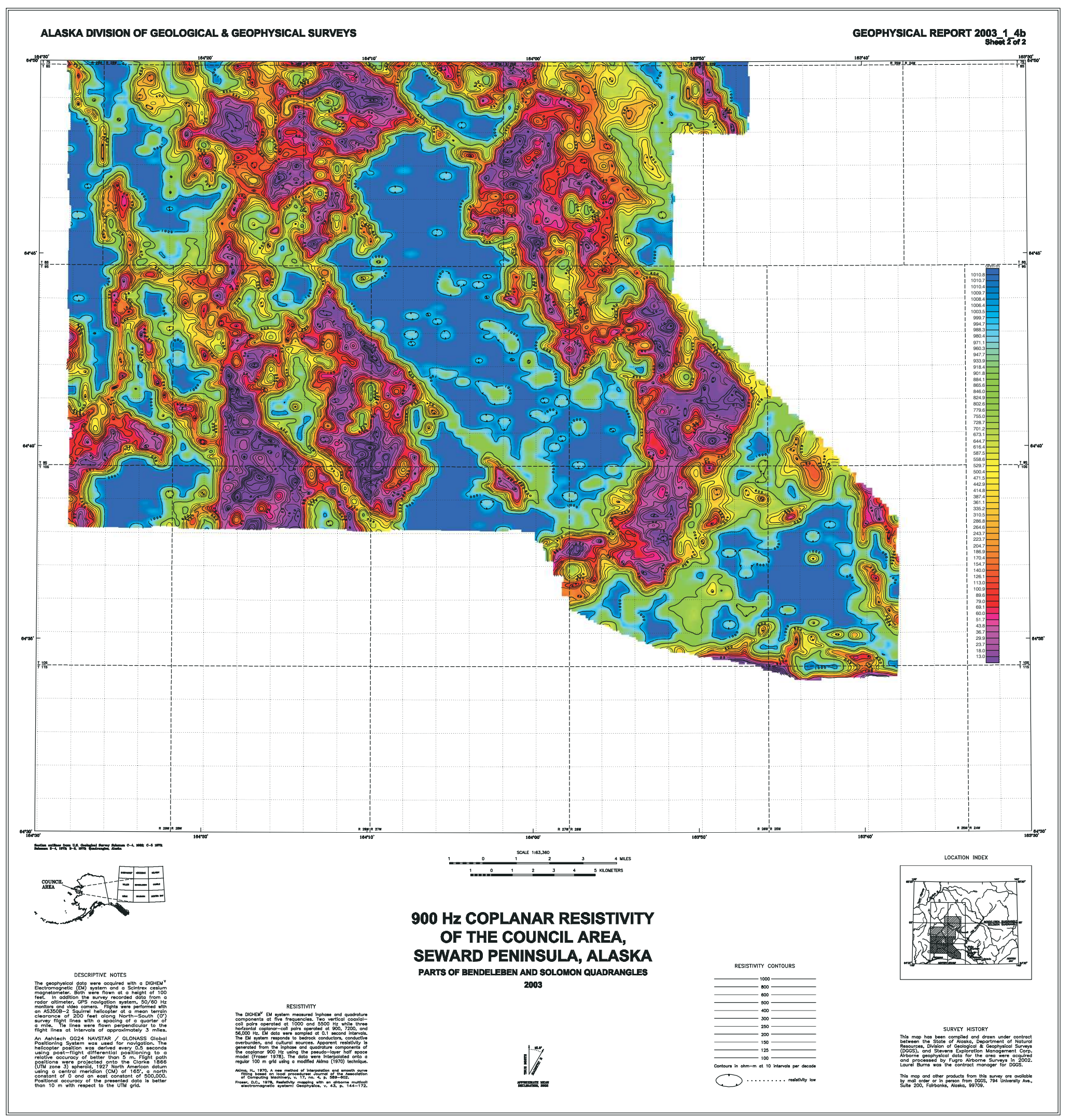




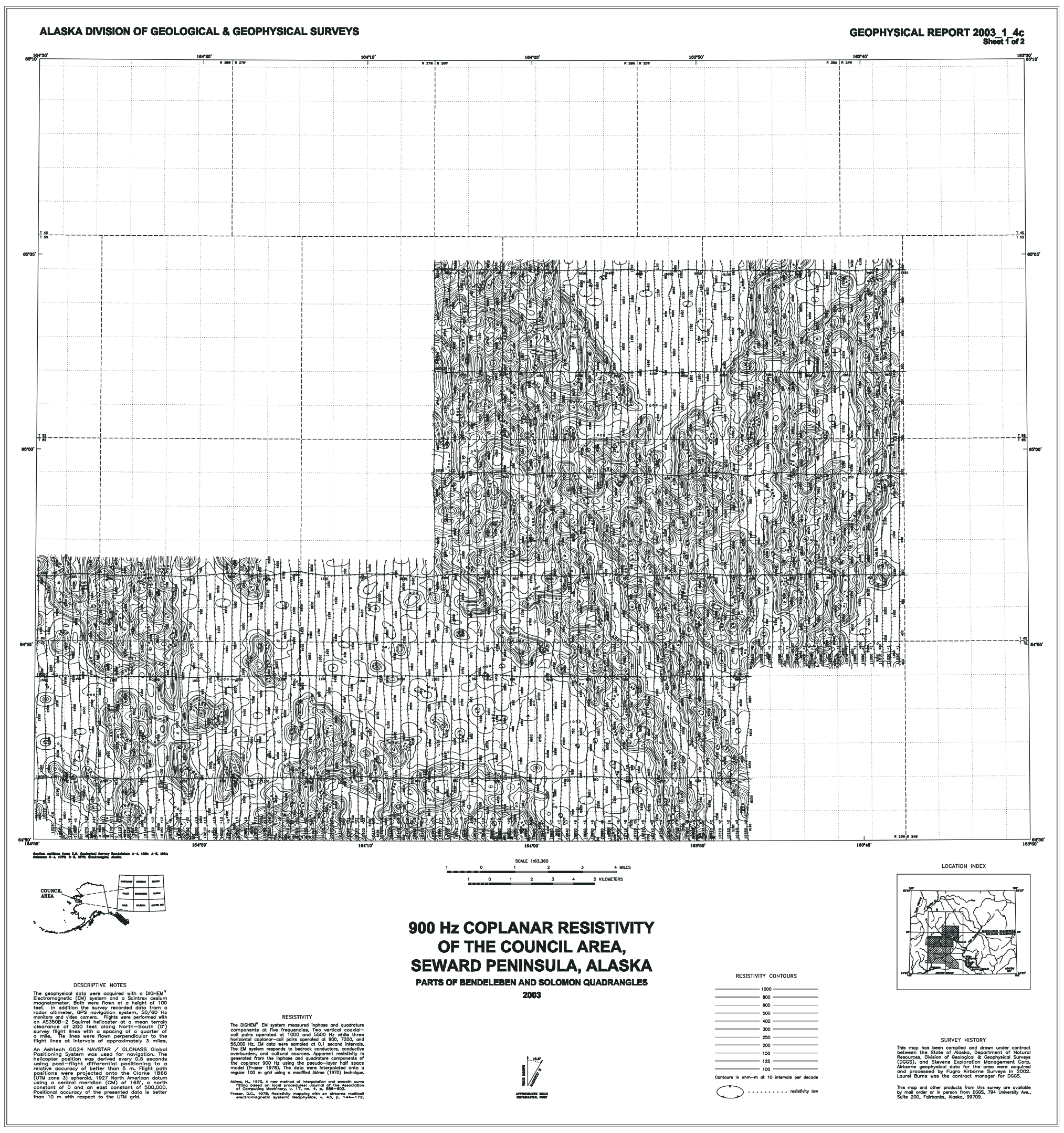




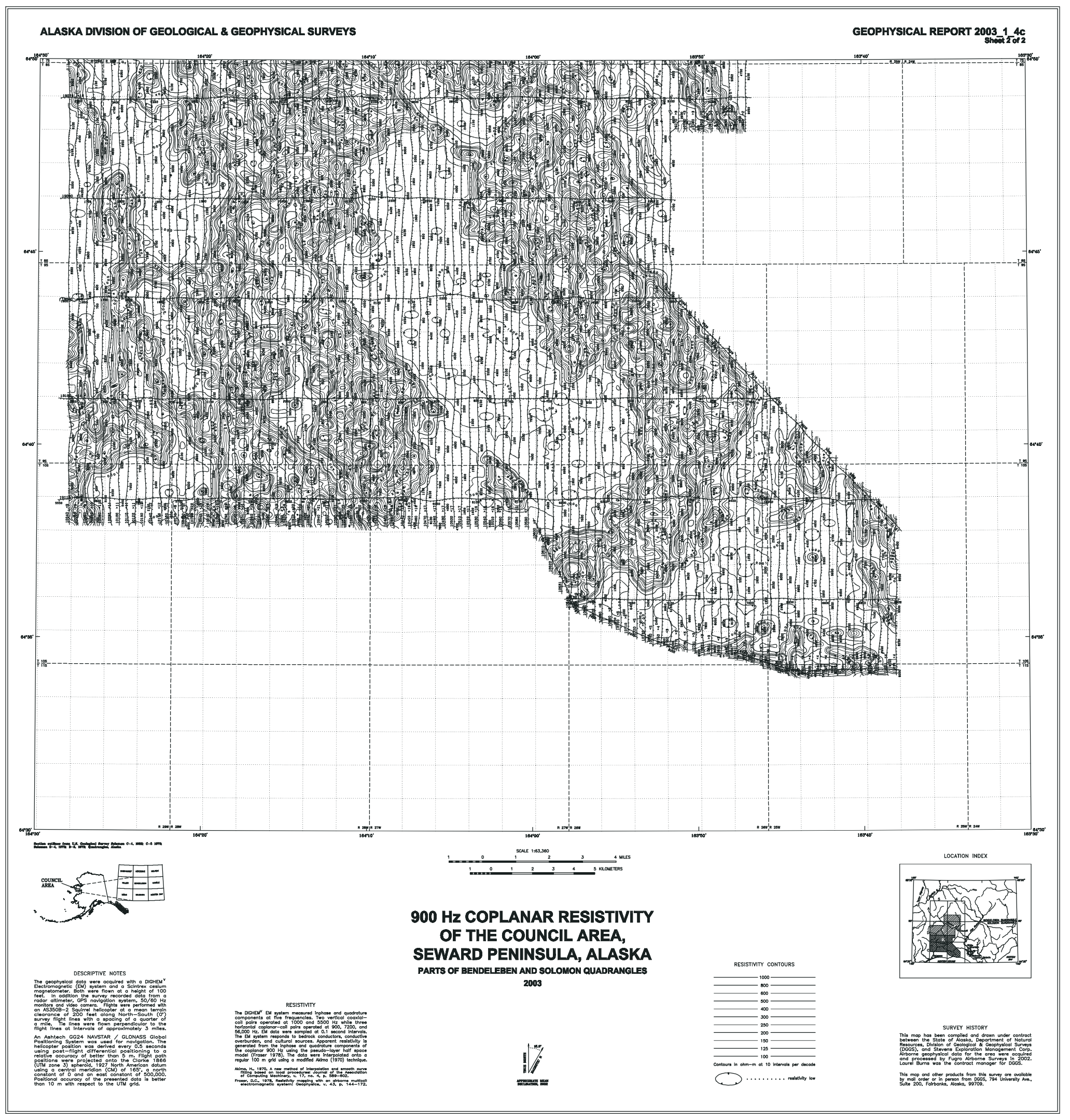




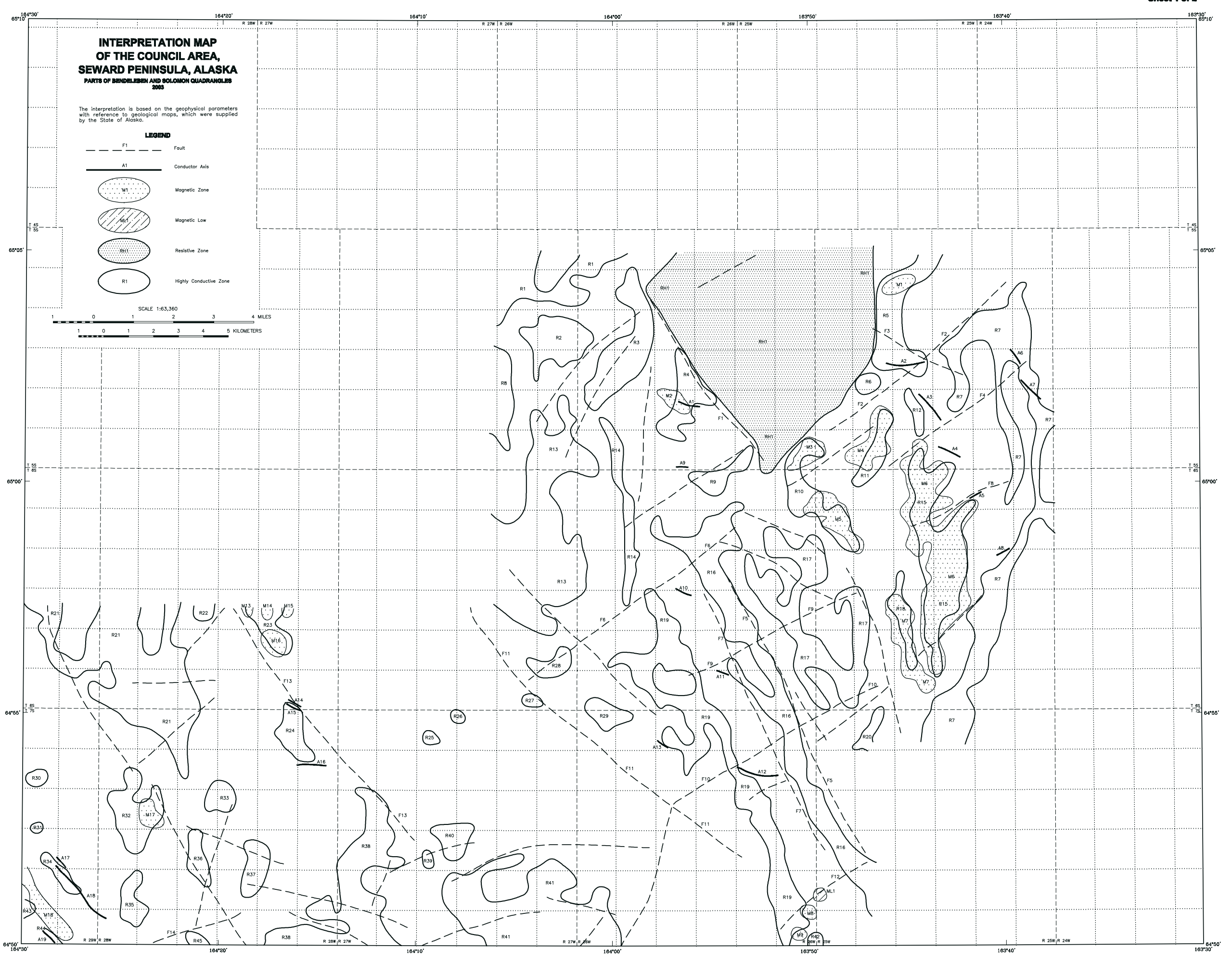




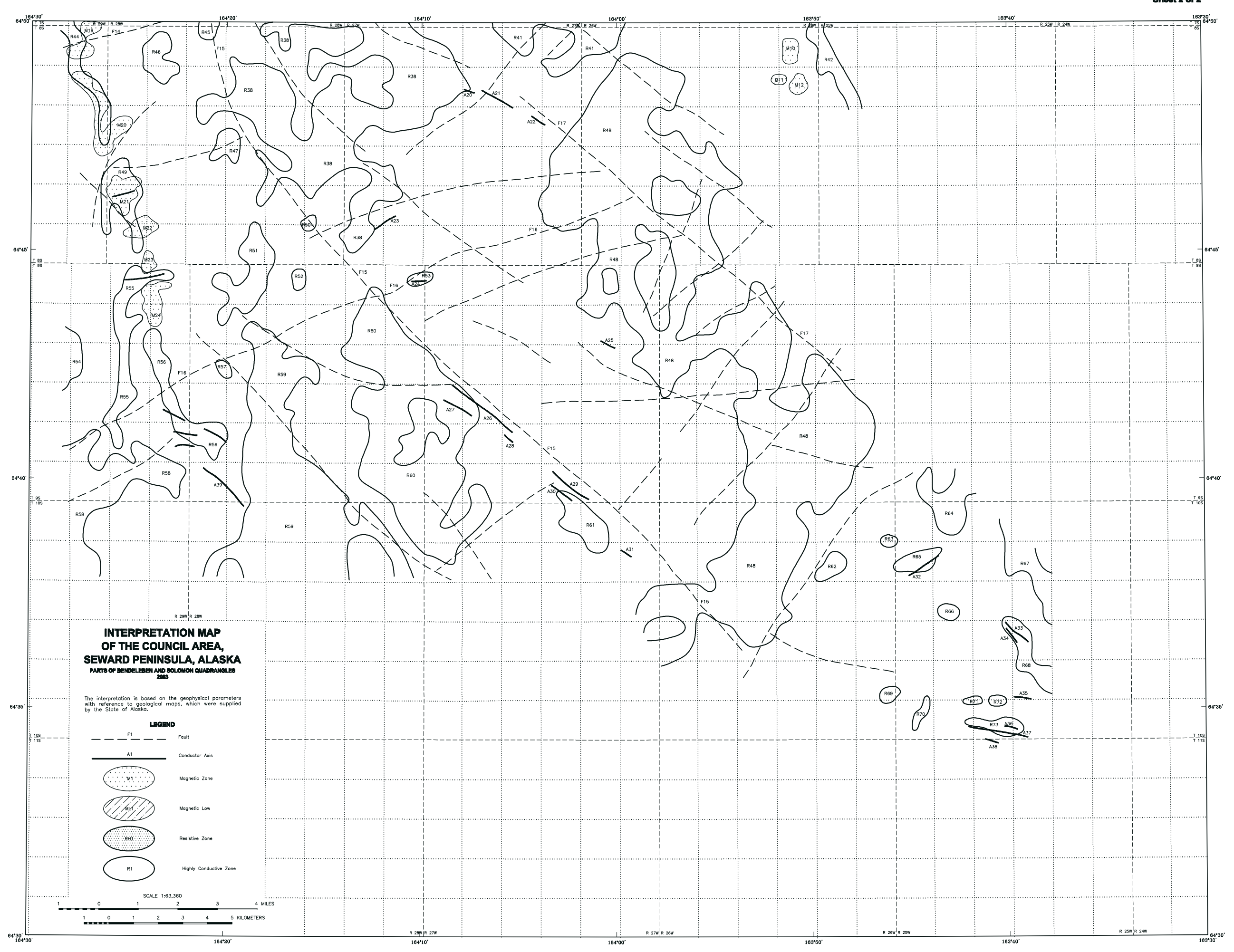




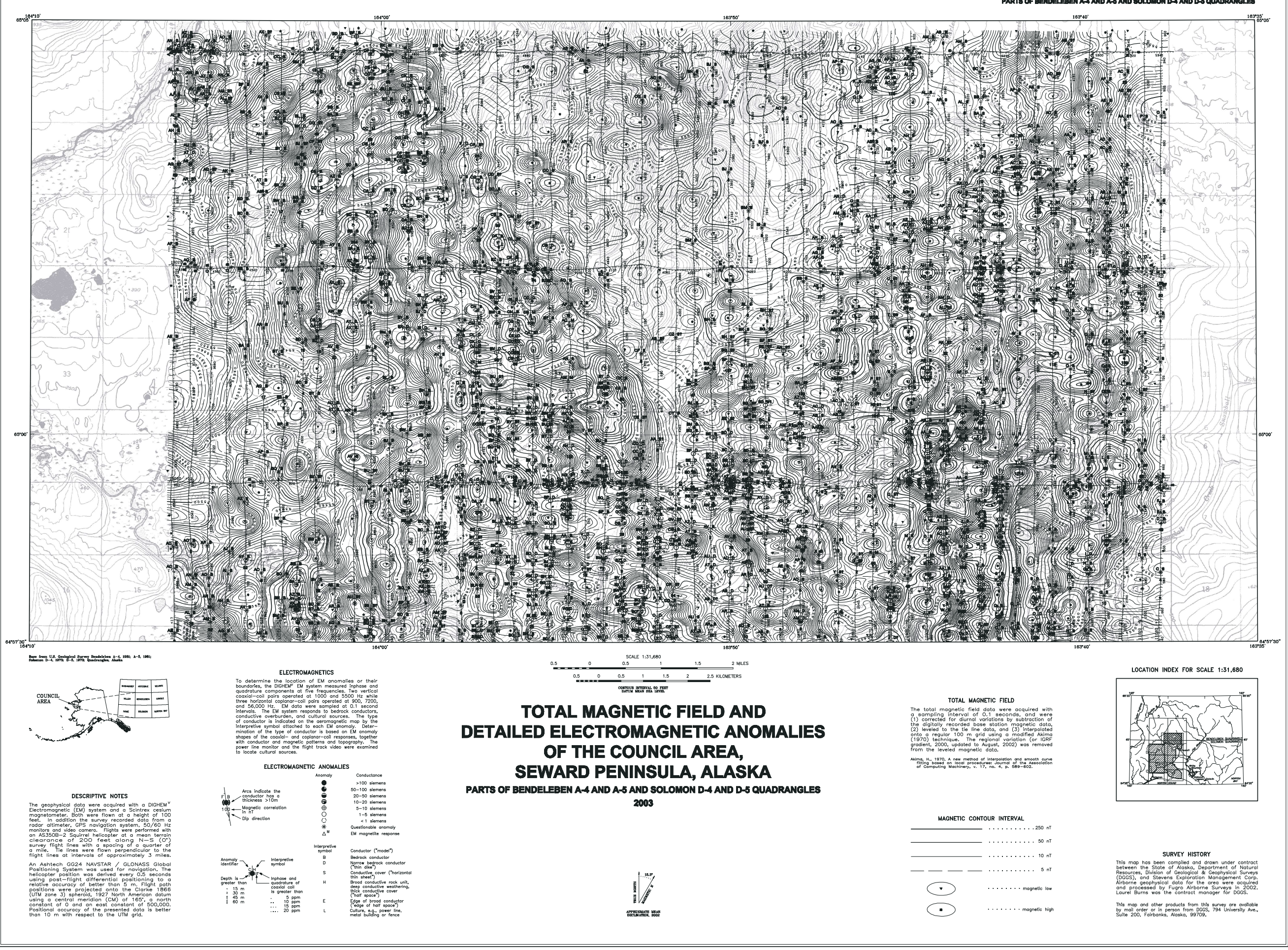




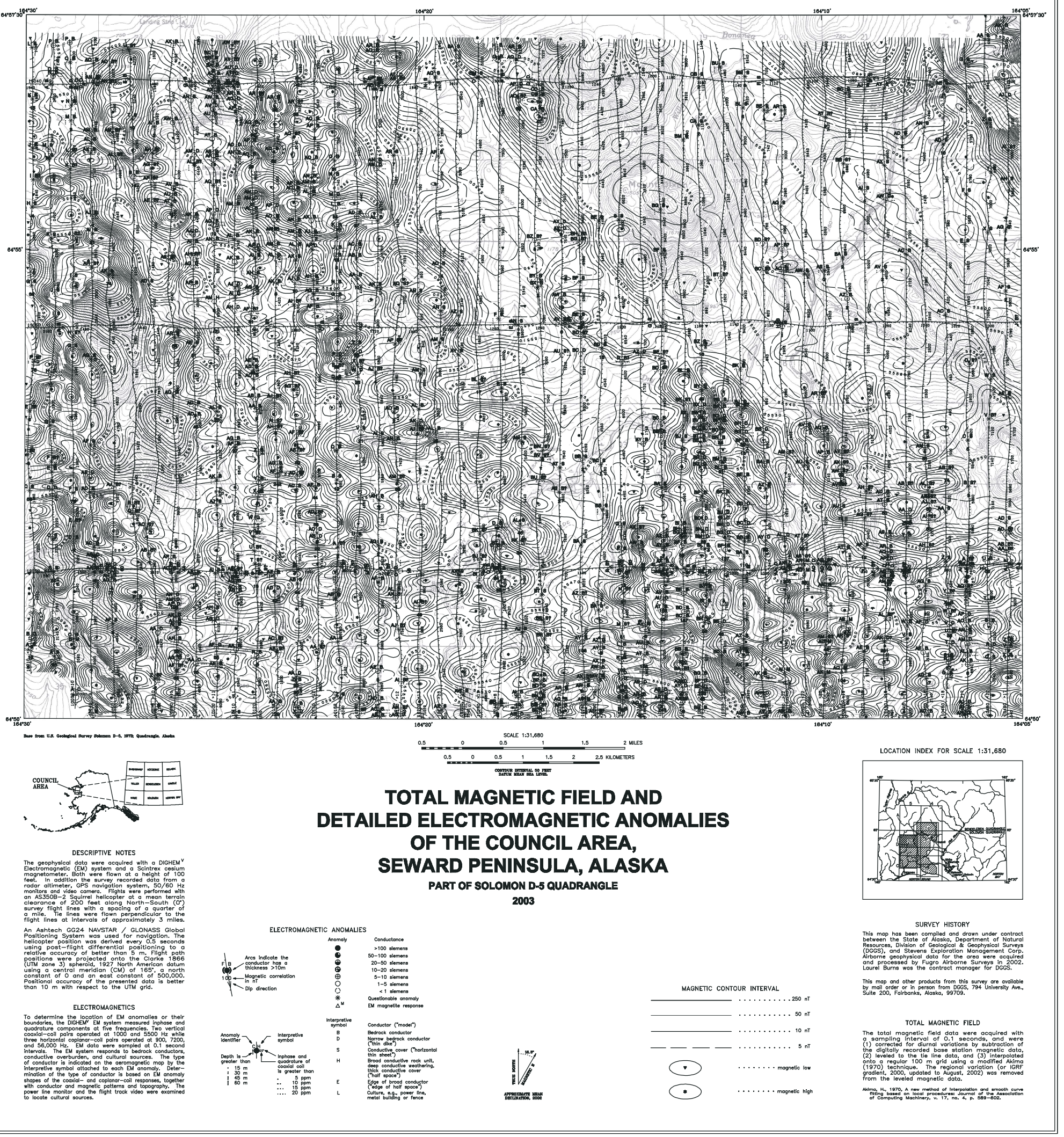




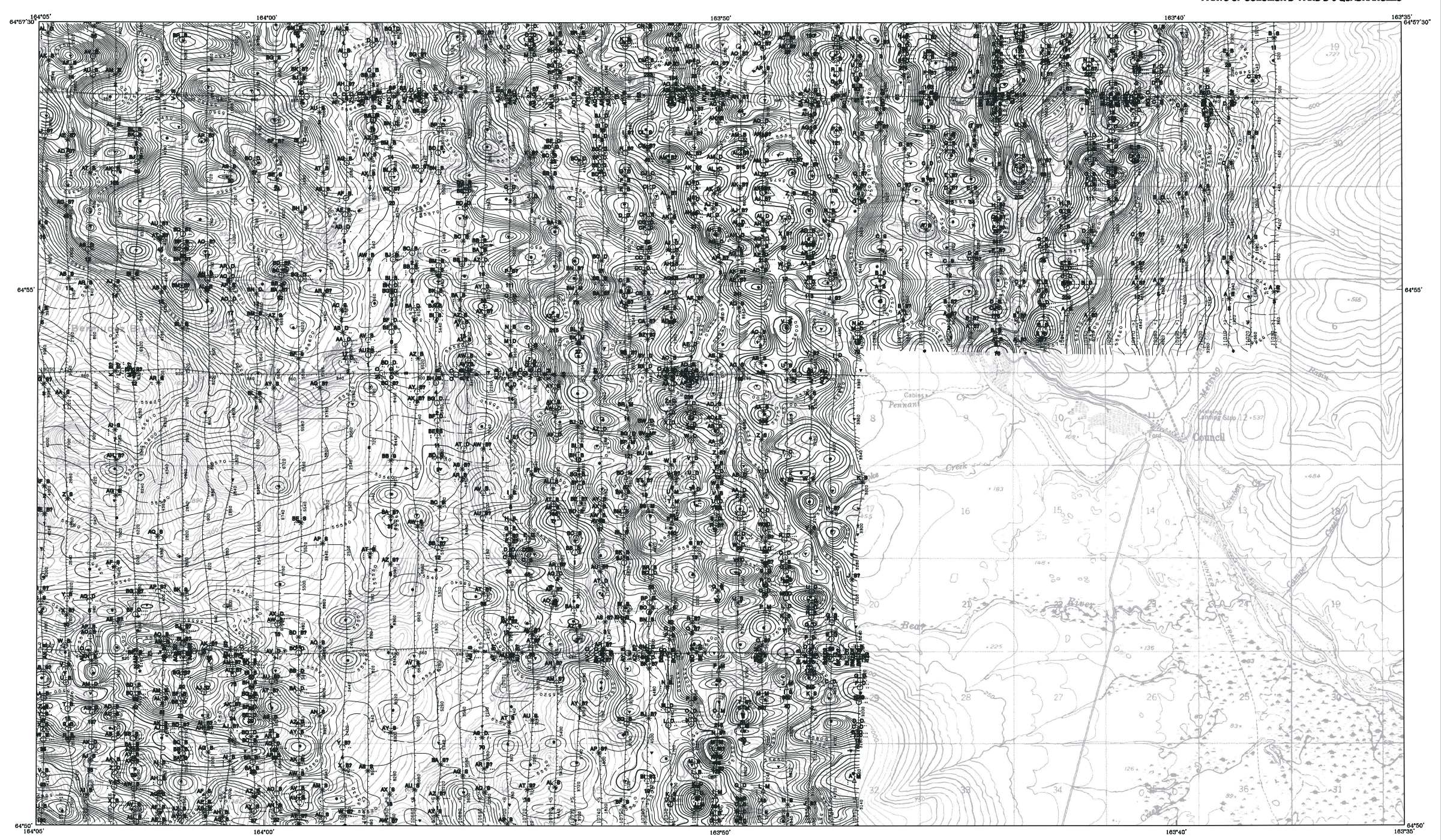

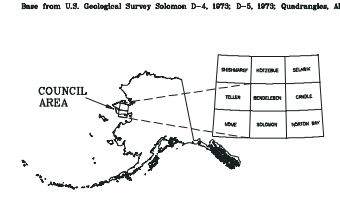

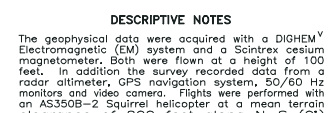

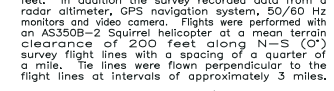

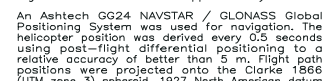

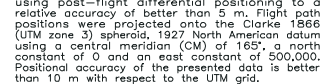

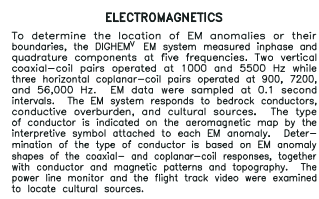

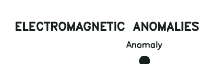

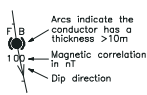

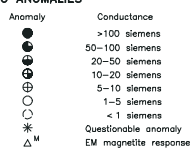

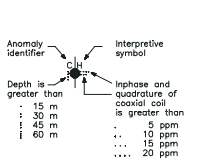

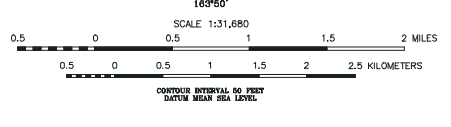

TOTAL MAGNETIC FIELD AND DETAILED ELECTROMAGNETIC ANOMALIES OF THE COUNCIL AREA,

SEWARD PENINSULA, ALASKA

PARTS OF SOLOMON D-A AND D-5 QUADRANGLES

$$
2003
$$
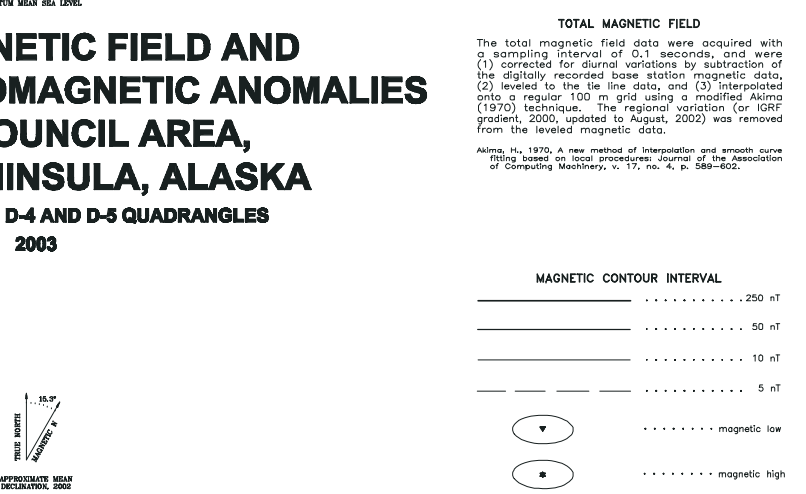

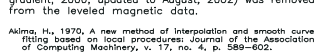

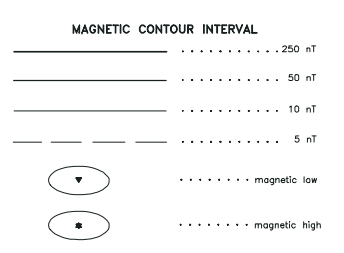

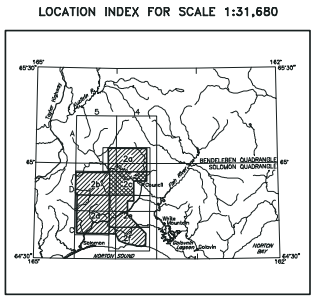

SURVEY HISTORY

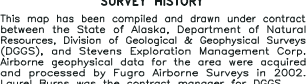

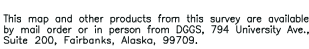




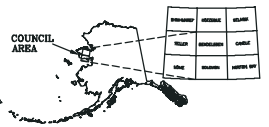

DESCRIPTIVE NOT

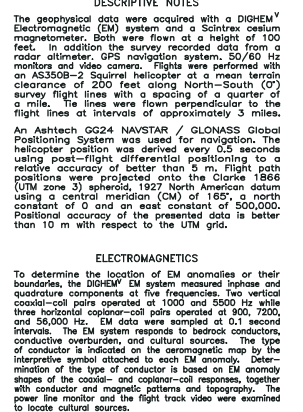

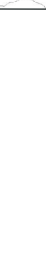

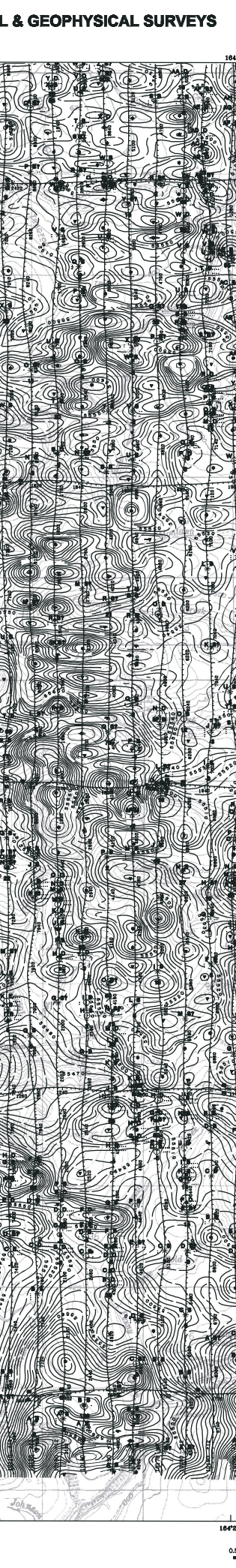

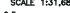

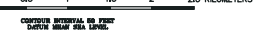

TOTAL MAGNETIC FIELD AND DETAILED ELECTROMAGNETIC ANOMALIES OF THE COUNCIL AREA, SEWARD PENINSULA, ALASKA

2003

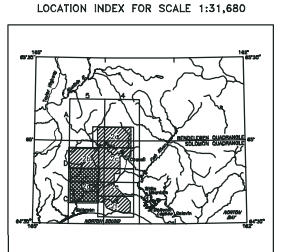

PARTS OF SOLOMON C-5 AND D-5 QUADRANGLES
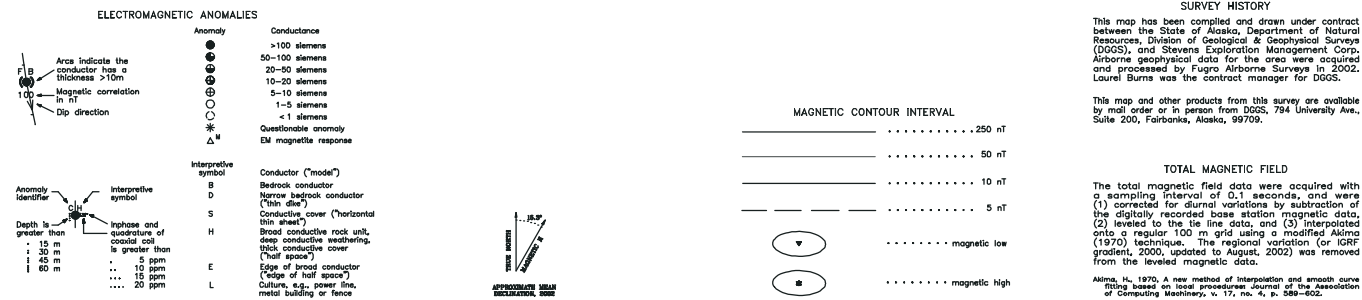

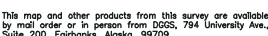
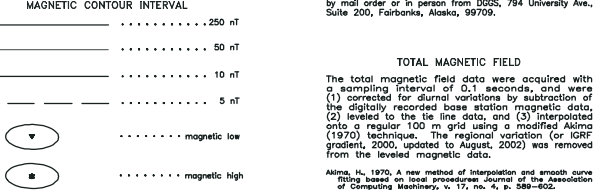


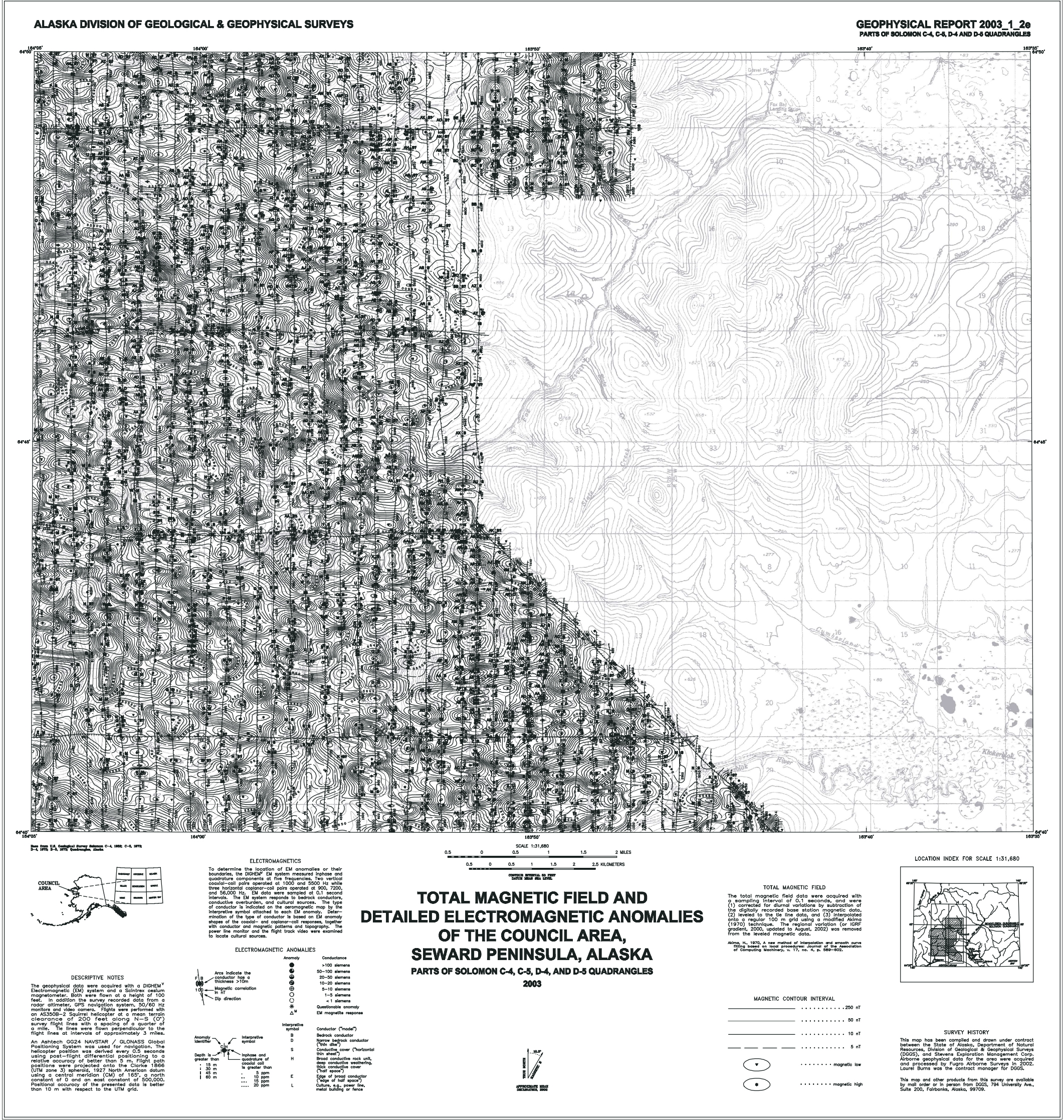




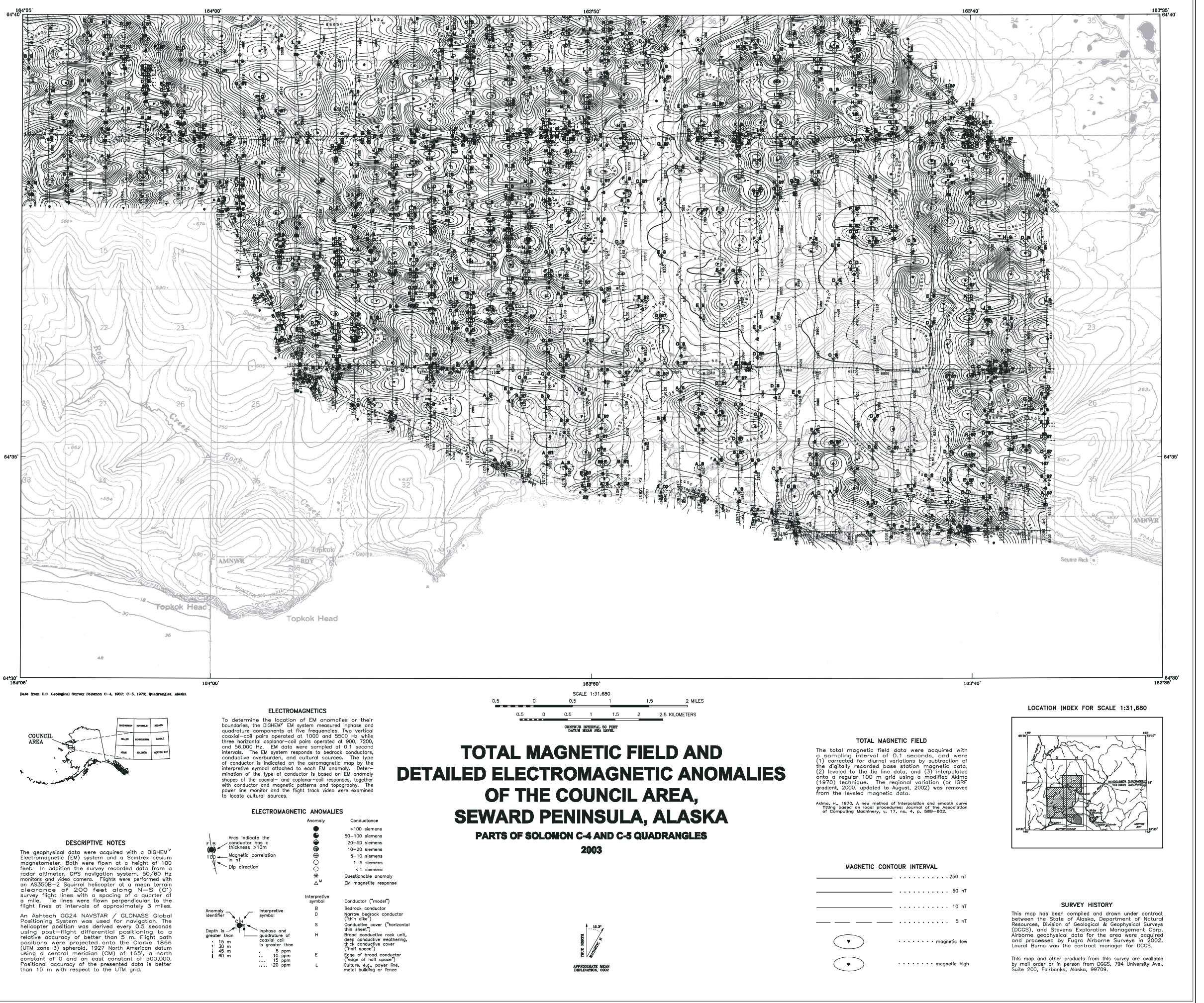




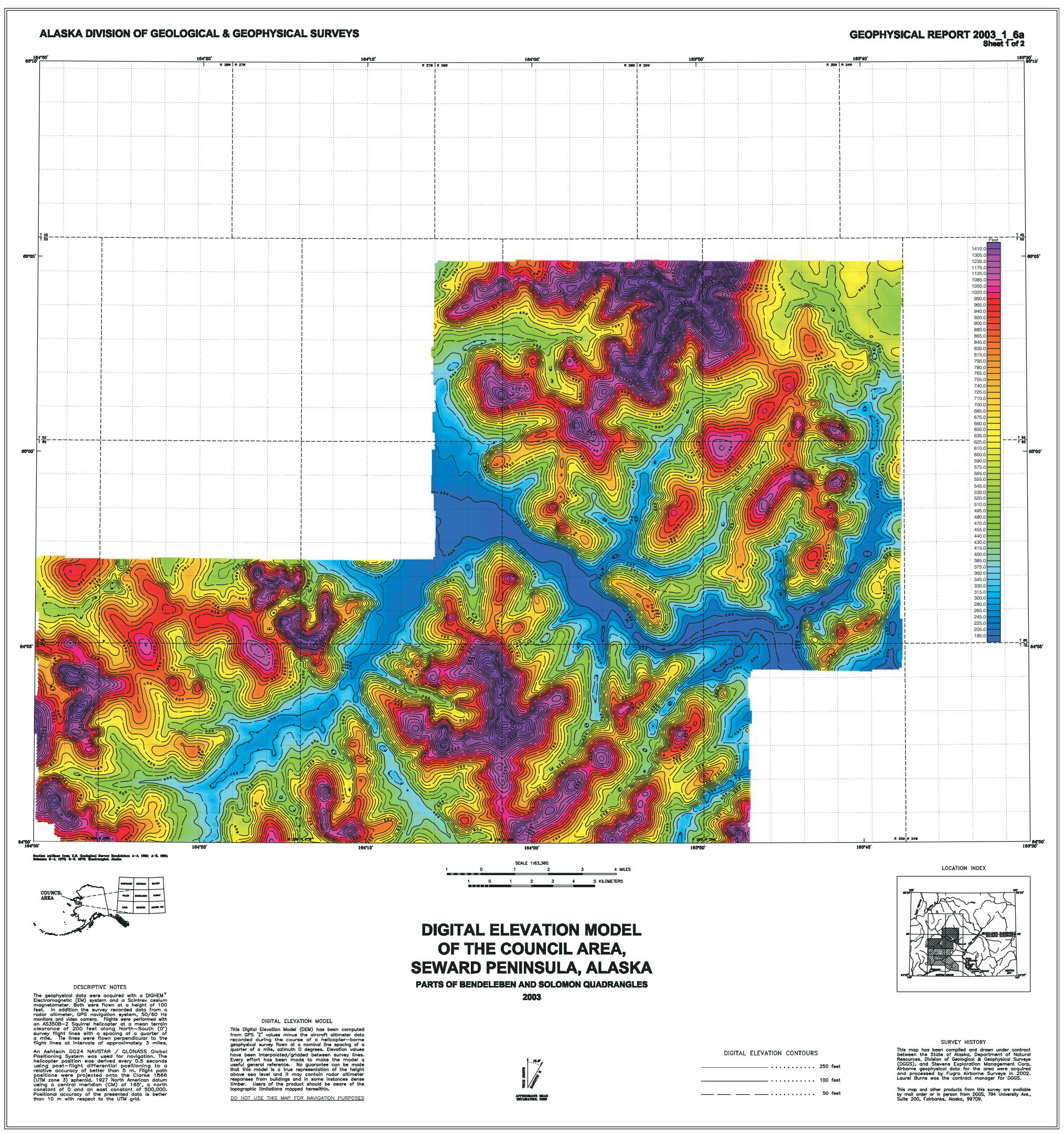




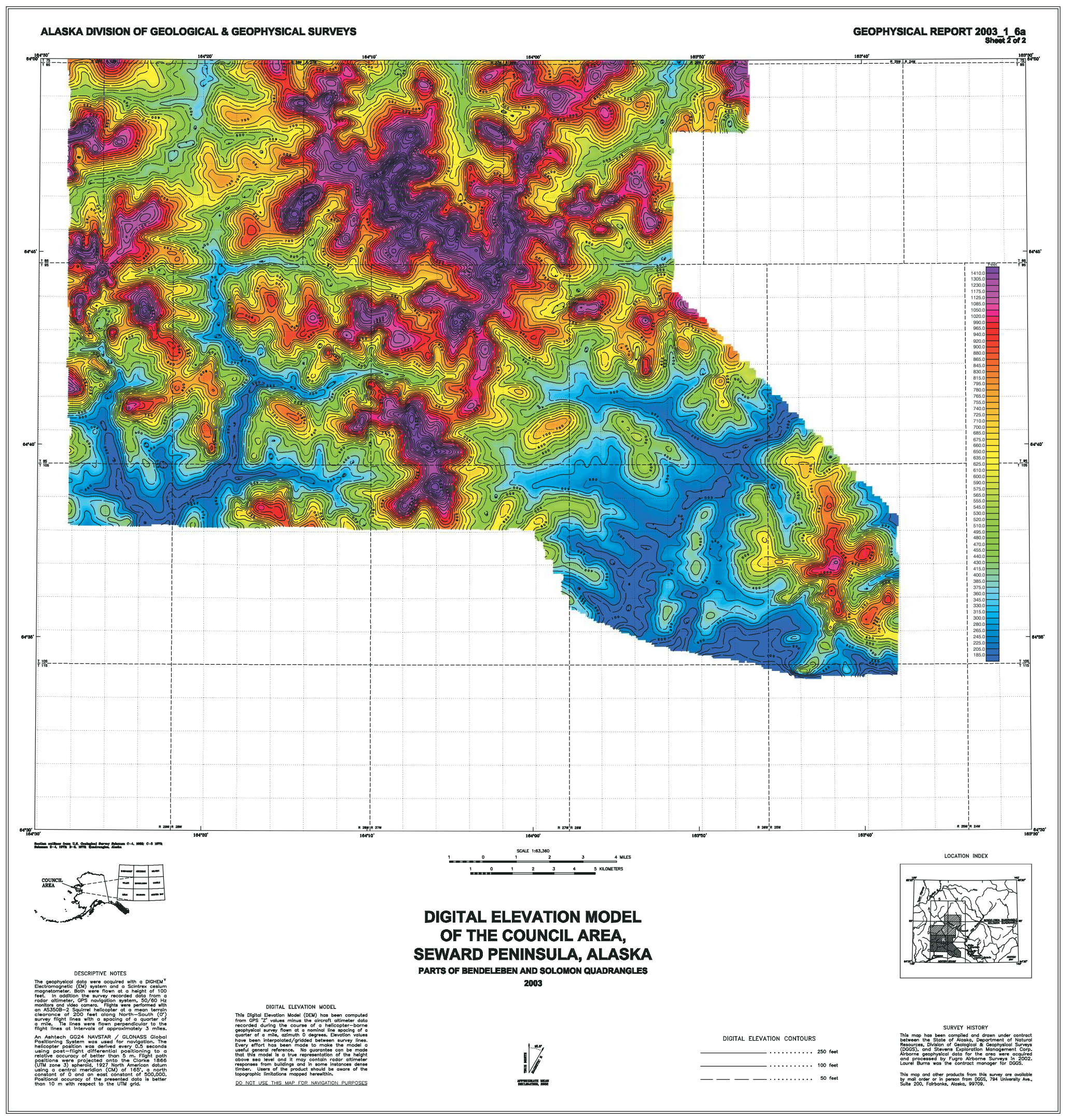

